Article

\title{
Towards Italian Opera Houses: A Review of Acoustic Design in Pre-Sabine Scholars
}

\author{
Dario D'Orazio ${ }^{1, *,+}$ (i) and Sofia Nannini ${ }^{2}$ (D) \\ 1 Department of Industrial Engineering, DIN University of Bologna, 40126 Bologna, Italy \\ 2 Department of Architecture and Design, DAD Politecnico di Torino, 10125 Torino, Italy; \\ sofia.nannini@polito.it \\ * Correspondence: dario.dorazio@unibo.it; Tel.: +39-051-2090549 \\ + Current address: Viale Risorgimento 2, 40126 Bologna, Italy.
}

Received: 31 December 2018; Accepted: 22 February 2019; Published: 1 March 2019

\begin{abstract}
The foundation of architectural acoustics as an independent science is generally referred to Sabine's early studies and their application. Nevertheless, since the 16th Century, a great number of authors wrote essays and treatises on the design of acoustic spaces, with a growing attention to the newborn typology of the Opera house, whose evolution is strongly connected to the cultural background of the Italian peninsula. With roots in the Renaissance rediscovery of Vitruvius's treatise and his acoustic theory, 16th- to 19th-Century Italian authors tackled several issues concerning the construction of theatres-among them, architectural and structural features, the choice of the materials, the social meanings of performances. Thanks to this literature, the consolidation of this body of knowledge led to a standardisation of the forms of the Italian Opera house throughout the 19th Century. Therefore, the scope of this review paper is to focus on the treatises, essays and publications regarding theatre design, written by pre-Sabinian Italian scholars. The analysis of such literature aims at highlighting the consistencies in some 19th-Century minor Italian Opera houses, in order to understand to what extent this scientific and experimental background was part of the building tradition during the golden age of the Italian Opera.
\end{abstract}

Keywords: opera house; cultural heritage; shape optimisation; room acoustics

\section{Introduction}

Almost all Italian Opera houses with outstanding room acoustical reputations have been built before what is considered the beginning of architectural acoustics as an independent science, which dates back to 1898 [1,2]. The acoustics of historic Opera houses can be considered the result of a Darwinian type evolution, with architects designing halls inspired by the success of former "good" halls, frequently destroyed by fires. According to previous works [3-5], it is possible to identify three main room acoustic design approaches which were the starting point of this evolutionary process: the theory of "circulation of sound", the proto-geometrical acoustics and the "echo theory".

The theory of "circulation of sound" was based on the Renaissance rediscovery of Vitruvius's writings [6]. The Latin author argued that the voices of actors should be unobstructed in order to create favorable room-acoustics [5]. Such method thus influenced the building of auditoria with round shapes, rounded proscenium arches, without obstructions which "slowed the circulation" or "broke the voice" [3-5].

The proto-geometrical acoustics-from the 17th Century-was based on the assumption that the trajectory of sound was analogous to the sound rays reflected from a surface. Therefore, sound could be conveyed by modifying the plan shape. The similarity between light and sound was first assumed by Giuseppe Biancani (1566-1624), who defined the so-called "echometria" [7]. Assuming that rays 
spread evenly over a plan after being reflected from parabolic or elliptically shaped walls [5], scholars discussed the best plan for the cavea: elliptical, bell- and horseshoe-shaped-the latter becoming the standard shape for 19th-Century theatres. Moreover the raising of proscenium arches, directly bound both to scenography and acoustics, increased the early reflections-or, better, the first reflection; lastly, the shape of the ceilings was never designed as concave in order not to concentrate reflections.

The "echo-theory" is a recent guideline based on geometrical acoustics which dates back to the end of the 18th Century $[5,8]$. This theory focused on a "quantification of the perception threshold between direct and reflected sounds: when a first order reflection exceeded this threshold, an echo would be perceived, which was considered detrimental for the acoustics of the hall" [5]. Instead of uniform radiation pattern, a directional one was assumed and the "echo-theory" guideline was grounded on simple measurements, which employed a speaking person and a human observer judging audibility or intelligibility as a function of distance and direction. Because of such voice directivity and propagation guideline, the size of audience areas in Opera houses was limited.

Analyses through virtual reconstructions [9-13] provided further information on the acoustic quality of historical theatres, also taking into account the occupied conditions. The results generally highlighted situations that are more reverberating than the current standards. If we compare these conditions to the limited available literature on the current state of such theatres, following the ordinary measuring procedures, it is possible to define local building characteristics that are deeply connected to the politic fragmentation of Italy [14-20]. A collation of such data was suggested by Prodi et al. [20]: this work sought the correlation between acoustic and geometric descriptors of the environment (volume, seats, volume/audience ratios, etc.). Moreover, some authors [21,22] suggested the adjustment of some descriptors used in international theatres to the small-medium typology of Italian Opera houses. Lastly, Garai et al. [23] examined the coupling effects between fly tower and cavea.

Thanks to the reading of several original texts, spanning between the 16th and the 19th Century, this paper aims at adding another contribution to the scientific discussion on the pre-Sabine theories. Indeed, these texts show a particular attention on materials and other features that can be interpreted by means of architectural acoustics.

\section{The Late-Renaissance Theatre}

Until the end of the 17th-Century, the acoustic spaces were treated using the Vitruvian categories, taken from Vitruvius's well known treatise De Architectura (On Architecture). The treatise was written around the 1st Century B.C. and rediscovered in the 15th Century, becoming one of the bases of Renaissance humanist culture. Vitruvius's theory on theatre design was based on the propagation of spherical sound waves-the so called "circulation" [4,5]:

- Dis-sonantes, when the circulation is dissipated by destructive interference provided by the architectural elements (hard and sharp corners, etc ...);

- Con-sonantes, when the environment increases the circulation;

- Circum-sonantes, when curved surfaces create a reverberation effect;

- Re-sonantes, when echo phenomena occur.

One of the first music rooms of the modern age was the Odeo Cornaro in Padua, designed by Giovanni Maria Falconetto (1468-1534) around 1524-1530 for the nobleman and patron Alvise Cornaro (1484-1566). This project was included by the architect and theorist Sebastiano Serlio (1475-1554) in his Sette libri dell'architettura (Seven Books of Architecture) [24]. Serlio's drawing of the Odeo Cornaro shows a central symmetric plan with four niches on the sides and it is covered by a dome (see Figure 1). This small room fully agreed with the features of Vitruvian circum-sonantes spaces, as the round niches increased the diffusivity (As Serlio writes, "Et li quattro niccij per la sua ritonditá concava ricevono le voci, \& le ritengono" (And the four niches, due to their round concavity, receive the voices and retain them) [24].). Indeed, this space was oriented to music listening rather than mere speech. 
Serlio's great interest in theatre design can be particularly understood by reading the last pages of his second book on perspective, where a specific paragraph is dedicated to theatres and scenographies. By blending his readings of Vitruvius's acoustic theory and the laws of geometrical perspective, Serlio included a section and a plan of what might have been the model of his timber theatre designed for the courtyard of the palazzo Porto in Vicenza in 1539. On one hand, the first terraces of the cavea are semicircular and then acquire an almost elliptical shape [25]; on the other hand, the stage shows a sloped surface for a better perspective view from the audience (see Figure 2).

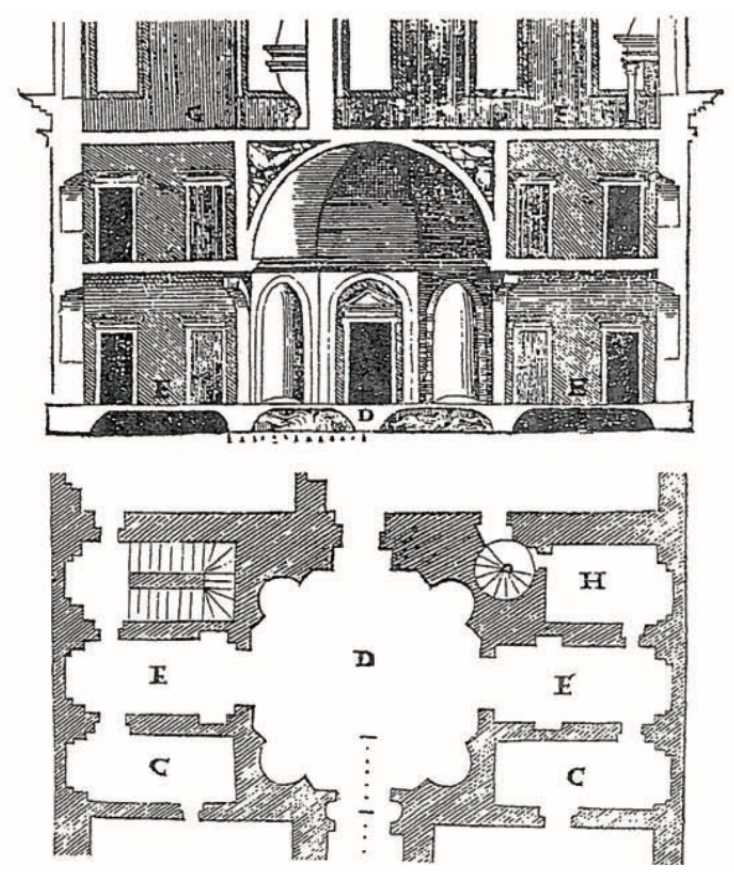

Figure 1. Plan of Odeo Cornaro in Padua (Hall D in the figure) (after [4]).
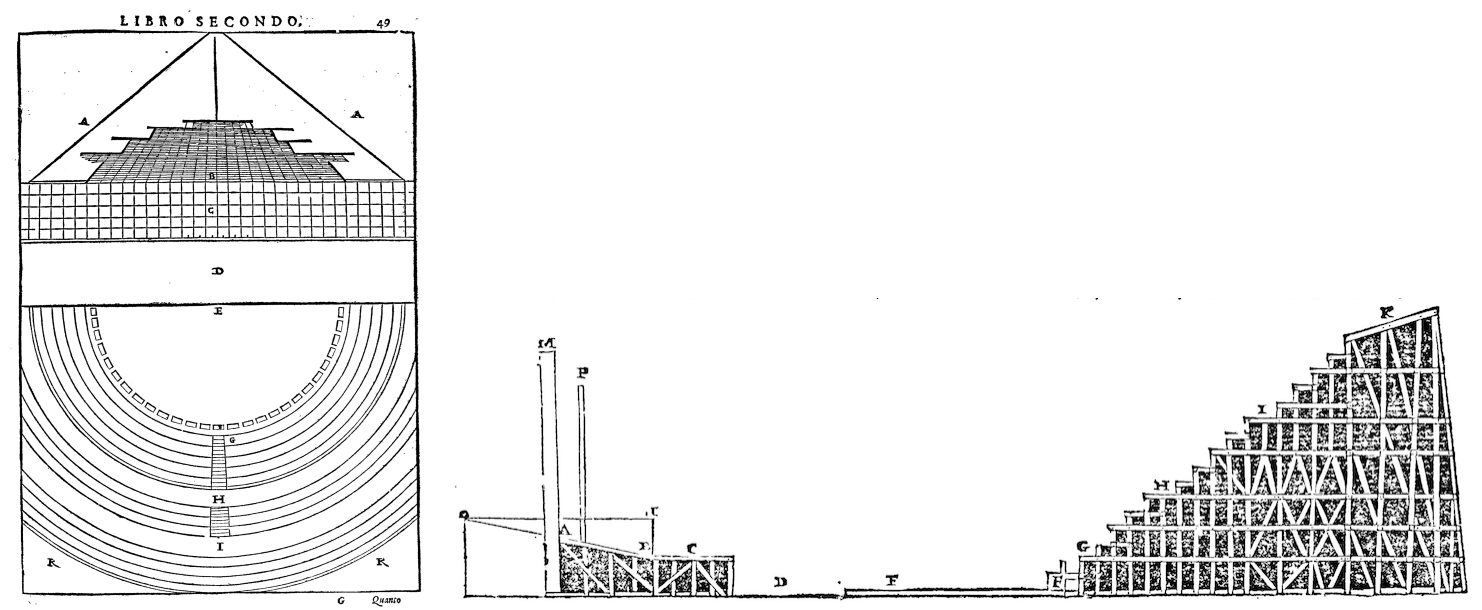

Figure 2. Plan and section of Sebastiano Serlio's timber theatre, in the book dedicated to Perspective (after [24]).

However, it is important to keep in mind that Vitruvius's acoustic and musical theory was based on considerations that mainly regarded the propagation of the human voice, as this was the key element of ancient Graeco-Roman theatre. Therefore, the acoustics of Greek and Roman theatres was generally revolving around the speech intelligibility of the actors [26-31]. Clearly, the evidence of these theatres' exceptional acoustics is due to their amphitheatrical shapes, and thus to the knowledge of the 
propagation of circular sound waves. However, it is not possible to affirm that the theory of the Latin author-despite his extensively quoting of Greek sources such as Aristotle's pupil Aristoxenus-was also applied to former Greek and Hellenistic theatres. Nevertheless, Vitruvius's rediscovered writings became the core of the Renaissance architectural theory, thus necessarily influencing also its acoustic outcomes [32,33].

A few decades after, with the aim of increasing the intelligibility of the speech and still following the models of Graeco-Roman theatres, late-Renaissance architects started experimenting with con-sonantes spaces. Such is the case of the Teatro Olimpico in Vicenza, by Andrea Palladio (1508-1580), inaugurated in 1585 with Sophocle's Oedipux Rex, with choruses by Andrea Gabrieli (1533-1585) $[4,13]$. The theatres of this period were characterised by steps and showed a reverberation higher to the present ones. In fact, the Odeo Cornaro shows a measured reverberation time at mid frequencies of $2.4 \mathrm{~s}$ in an unoccupied condition and a simulated reverberation time in an occupied condition of $1.3 \mathrm{~s}$ [34]; the Teatro Olimpico shows a measured reverberation time at mid frequencies of $3.3 \mathrm{~s}$ in unoccupied conditions and a simulated reverberation time of $2.2 \mathrm{~s}$ in occupied conditions [13]. Such acoustic conditions allowed a good intelligibility of the early writing styles of melodrama, as the Gabrieli's choruses in the Teatro Olimpico, as confirmed by historical sources [34,35] (see Figure 3).

At the same time, the development of acoustics was strongly connected to political and religious issues prompted by the event of the Protestant Reformation and the Council of Trent (1545-1563), which opened to the Counter-Reformation. On one hand, the Lutheran culture was oriented to the act of reading, due to the availability of printed Bibles thanks to Gutenberg's innovation. On the other hand, the reformed Catholic culture gave more importance to the act of listening, due to the changes in ritual offices. For example, coffered wooden ceilings in churches were preferred by Jesuits due to the decrease in reverberation time and increase in speech intelligibility [4]. An increasing interest in the propagation of sound was collected by the Jesuit Giuseppe Biancani (1566-1624), who published in 1620 the essay Sphaera Mundi [7], whose third paragraph is titled Echometria, idest Geometrica tractatio de Echo (Echometry, i.e., the Geometric Treatise of Echo). Biancani's Echometria opened a new branch of scientific knowledge blending sound and optics, which will be further called Acustica (Acoustics).

In this cultural environment, the building of the theatres corresponded to the birth of a new form of representation: the so-called Melodrama, which integrated various types of performance: mélos meaning singing, drama meaning acting. Indeed, the word Opera in Latin is the plural of opus, which means "act, performance". In the last decades of the 16th Century, the performance acquired a semi-public dimension-open to the Ruler and the court-and its own independent architecture. In the spaces designed for melodrama, one of the most significant aspects is the structural and typological background, deriving from the form of the Roman Basilica [36]. In fact, they were composed of a rectangular body ending with an apse, becoming, respectively, the audience and the stage. The theatre plan was typically divided into areas with different functions: the cavea for the audience, the stage and the rooms behind it reserved for the staff and for the artists. This is the case of Teatro all'antica (Ancient-Style Theatre) in Sabbioneta (1588-1590), by Vincenzo Scamozzi (1548-1616), which became the first building fully designed to be a free-standing theatre (see Figure 4). 

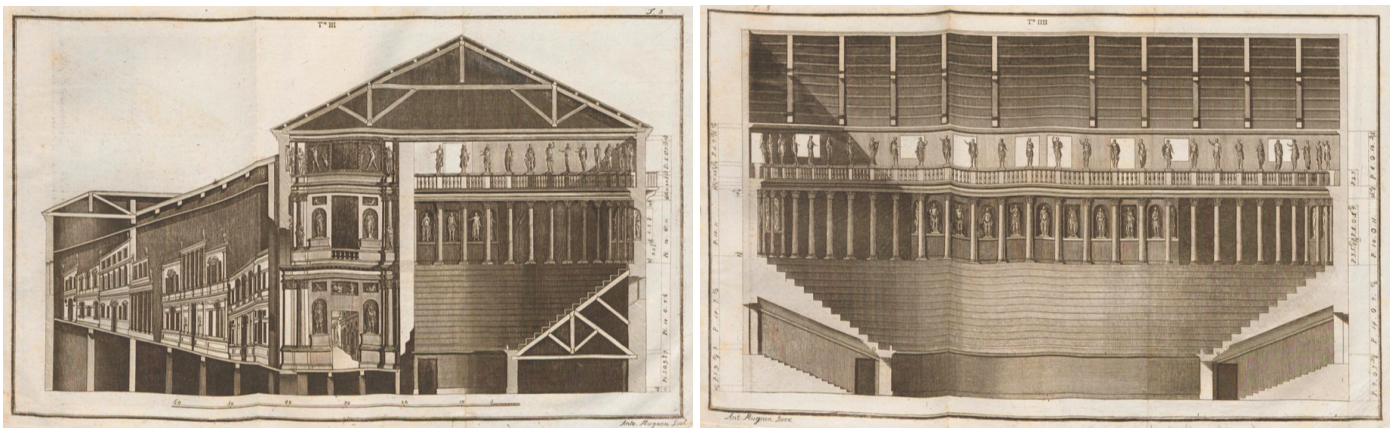

Figure 3. Section and view of Andrea Palladio's Teatro Olimpico in Vicenza (1585-1590) [37].

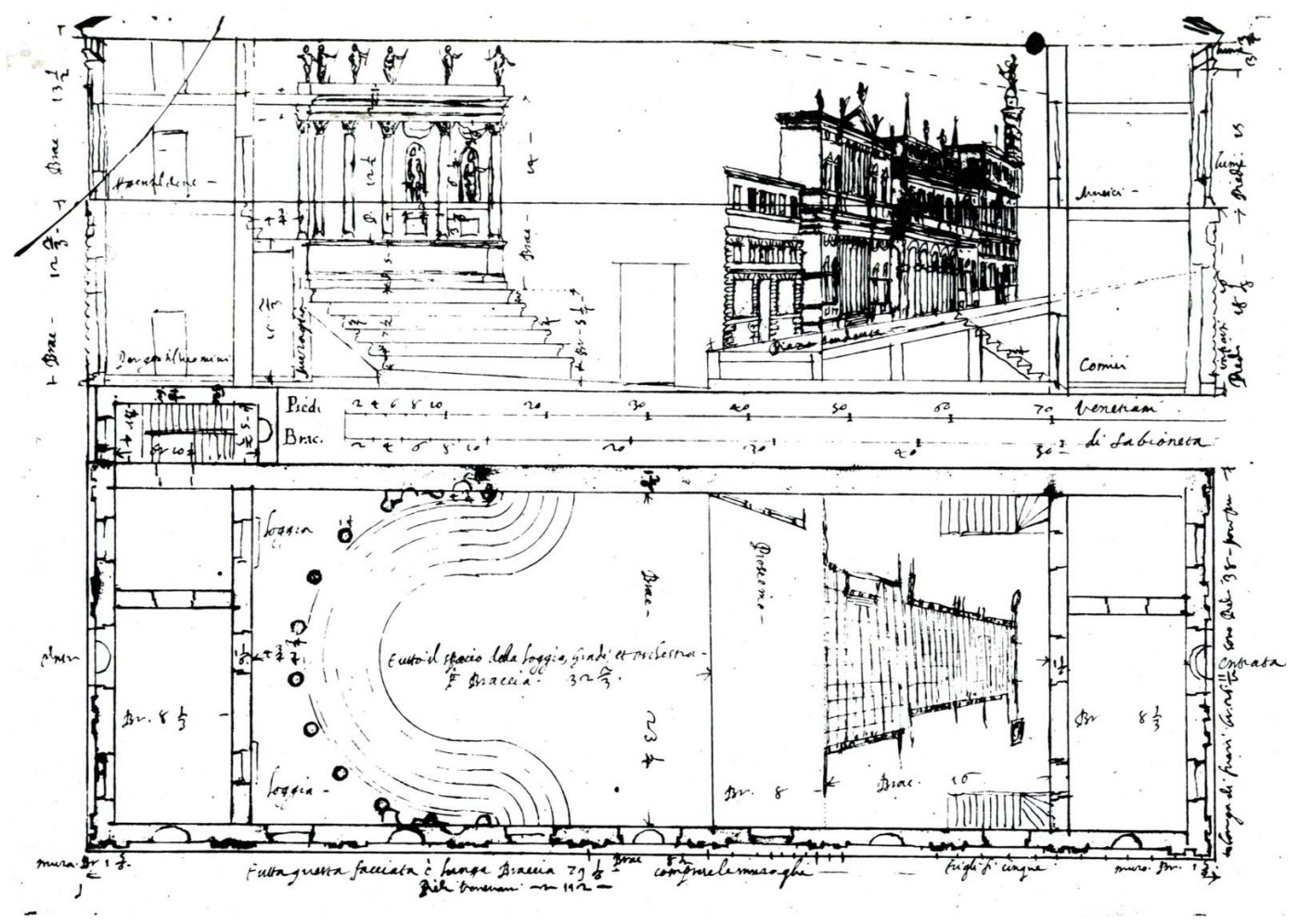

Figure 4. Vincenzo Scamozzi's draft of Teatro all'antica in Sabbioneta (1588-1590) [38].

\section{The Baroque Theatre}

At the beginning of the 17th Century, a new element entered the theatre design, which would influence both scenography and acoustics: the proscenium arch. This element, placed between the auditorium and the stage, was a direct consequence of the late-Renaissance studies on perspective-especially Serlio's aforementioned paragraph on perspective and scenography [39]. When it comes to its architectural use, the first and most famous architect constantly experimenting with proscenium arches was Inigo Jones (1573-1652). Inspired by his Italian architectural visits, he started introducing proscenium arches in his scenographies already in the first decade of the 17th Century, thus bringing the Italian perspective studies to Great Britain $[40,41]$.

At the same time, the Italian architect Giovan Battista Aleotti (1546-1636) introduced such new spatial disposition in two of his works: the Teatro degli Intrepidi in Ferrara (1605) [9], now demolished, and Farnese Theatre in Parma (1610) [11] (see Figure 5). In both structures, he built a proscenium arch which materialised the difference between what is real and what is a theatrical fiction. The dimensions of the scenic arch increased with the progressive standardisation of its form, together with the increasing complexity of Baroque scenery as in the works of Giacomo Torelli 
(1604-1678) [42], Nicola Sabbattini (1574-1654) [43] and Joseph Furttenbach (1591-1667) [44]. The role of this element was both visual and acoustical: on one hand, it provided a separation between the space of the representation and the space of the audience; on the other hand, it enhanced the first reflections from the stage and the orchestra, thus increasing the intelligibility in the stalls.

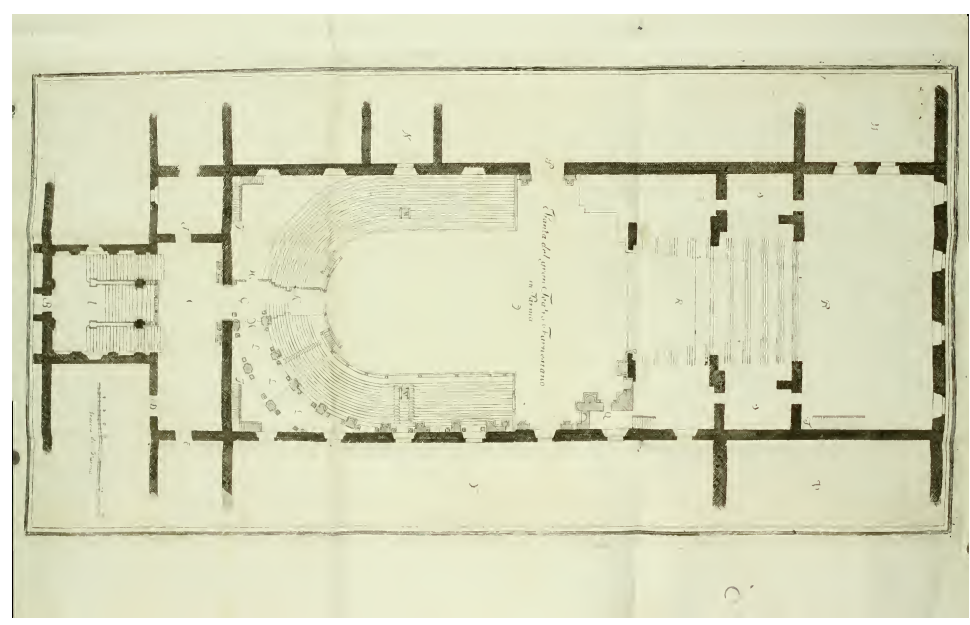

Figure 5. Plan of the Teatro Farnese in Parma (1610) (after [45]).

During the 17th Century, the most significant evolution of the theatre shape took place. It was due to the transformation of the acting performances, the appearance of the masques, and the renovation of the subjects. An important date, which represented a turning point in the theatre history, was 6th March 1637, when all social classes attended the inauguration of the theatre in campo San Cassian in Venice, by paying a ticket [46]. The paying audience and the new theatrical genre, the melodrama, consequently led to a redefinition of the theatre shape. In fact, the payment of a ticket for the performance made it possible to plan the theatrical seasons and the related investments, thus allowing for building permanent structures and to buy theatrical machineries [47]. The space for the audience became a field of architectural experimentations, with the main purpose of incrementing the seating capacity and improving the visual conditions of the attending public. At the same time, the upper classes began to claim for independent and private spaces, leading to the building of wooden partitions on the different tiers, creating the so-called "boxes". This spatial division reflected the social subdivision into classes. Moreover, such spatial configuration introduced a new kind of performance, where the main actors were the spectators themselves. Not only were the boxes rich and sophisticated showcases for the upper class, but they were also a window from which the richest could observe the common people sitting on the uncomfortable benches of the audience [46].

The first essay dealing with the so-called "Italian theatre" was written by the architect Fabrizio Carini Motta (16??-1699) in 1676 [48]. The author summarised all the architectural characteristics of the theatre and it recognised its different typologies: the 16th-Century typology with steps, with boxes or galleries, with boxes joined or not joined with the proscenium. He identified four main parts called "theatre square", "scene square", "boxes area" and "stage area". Concerning the so-called horseshoe typology, Carini Motta proposed two different models changing the ratio between the width and the length of the scene square, as shown in the author's drawing of Figure 6. The architect also dealt with the design of the partition between boxes: if the partitions were built perpendicular to the audience perimeter, the people sitting behind were not able to see the stage. Considering the possibility of choosing a focal point in the middle of the proscenium arch and building diagonal partitions by pointing to that focus, he noticed that there was unused space due to the presence of acute angles following Vitruvius's recommendation, allowing the public sitting behind to enjoy a better view of 
the stage area. Influenced by Carini Motta's observations, the Swedish architect Nicodemus Tessin The Younger (1654-1728) introduced some of these elements-rounded off back walls and a royal box - in the design for a theatre at the court of Denmark in the last years of the 17th-Century [5,49]. Furthermore, Carini Motta theorised a new kind of partition, shown in the last drawing of Figure 6. This was a mix between the aforementioned solutions, but it was unfortunately very difficult to realise. If a longer 'scene square' was needed, it was possible to set the wanted length with a line parallel to EF and to draw the biggest circle tangential to that line (see the last draw in Figure 6). According to Carini Motta's theory, all theatre dimensions had to be multiples or fractions of the theatre width. For instance, the height of the audience ceiling should have been higher than $2 / 3$ of the theatre width but smaller than the theatre width itself. On the other hand, he did not give specific indications about the height of the ceiling above the stage area: he only stated that it should have been higher than the audience vault.
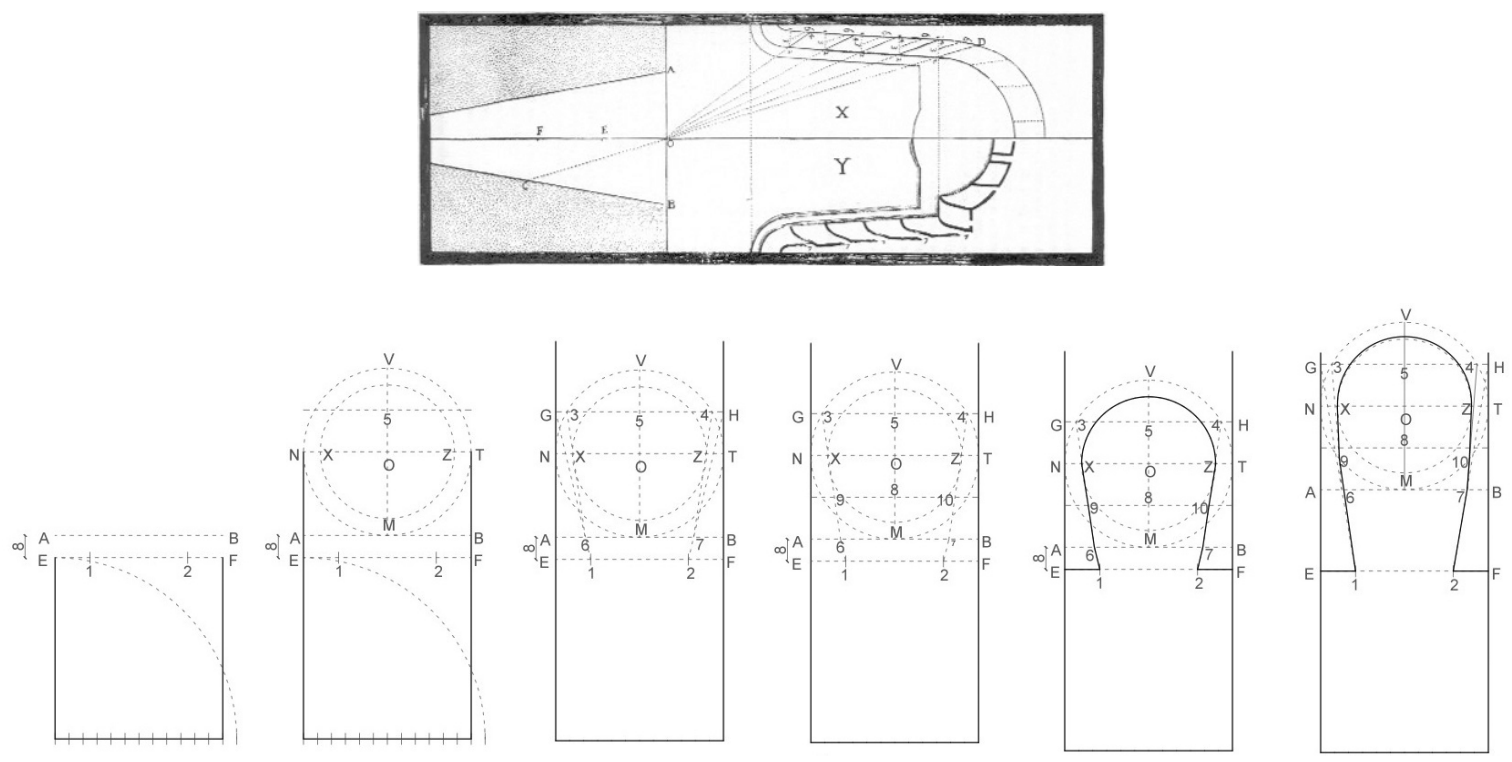

Figure 6. Fabrizio Carini Motta's original drawing (1676) [48] and redrawings [50]. The last figure refers to the possibility of obtaining a longer "scene square" if needed-there are more details in the text.

\section{The Evolution of Theatrical Architecture during the 18th Century}

During the 18th Century, the form and the functions of the theatre were optimised to host the melodrama: the stage was extended towards the audience-through the proscenium-in order to enhance the intelligibility of the soloists, the orchestra was placed in front of the stage; the boxes' arrangement was adapted for reasons of visibility. The mixtilinear shape of the Italian theatre was developed by many architects, who experimented with new solutions in order to improve the acoustical conditions and the possibility to have exact visuals (see Figure 7). 


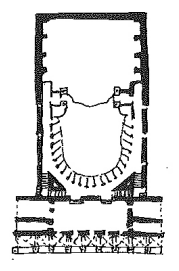

a

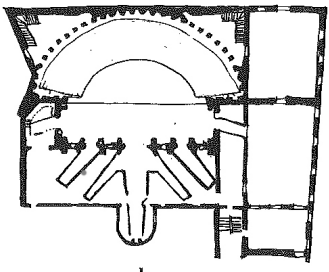

b

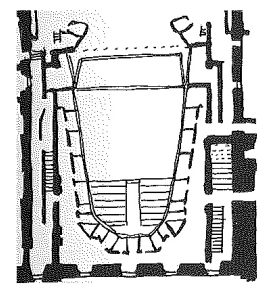

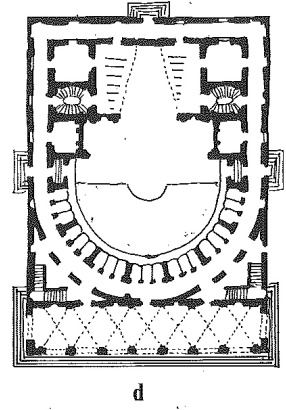

Figure 7. Theatre plan comparison: (a) bell shape: Teatro Comunale of Bologna (1763); (b) semielliptical shape: Teatro Olimpico of Vicenza (1585); (c) open U-shape: Molière hall in the Palais Royal of Paris (1640); (d) semi-circular shape: a design by Enea Arnaldi (1762); (e) circular shape: project by Vincenzo Ferrarese (1771) (after [36]).

Despite being extremely active in theatre and scenography design [51], the members of the famous Galli Bibbiena family did not write acoustic treatises with which we could directly retrace their thoughts. Nevertheless, some authors referred in their writings to the works by the Galli Bibbiena architects. For example, Francesco Algarotti (1712-1764) ground his study Saggio sopra l'opera in musica (Essay on the Opera, 1764) [52] on the works of Ferdinando Galli Bibbiena (1657-1743) and his sons Giuseppe (1696-1757) and Antonio (1697-1774). The former designed the Margravial Opera House in Bayreuth (1750) and several theatres in Europe; the latter designed the Teatro Comunale in Bologna (1763), the Teatro Scientifico in Mantua (now Teatro Bibiena,1769) and theTeatro dei Quattro Nobili Cavalieri in Pavia (now Teatro Fraschini, 1773) (see the plans in Figure 8).

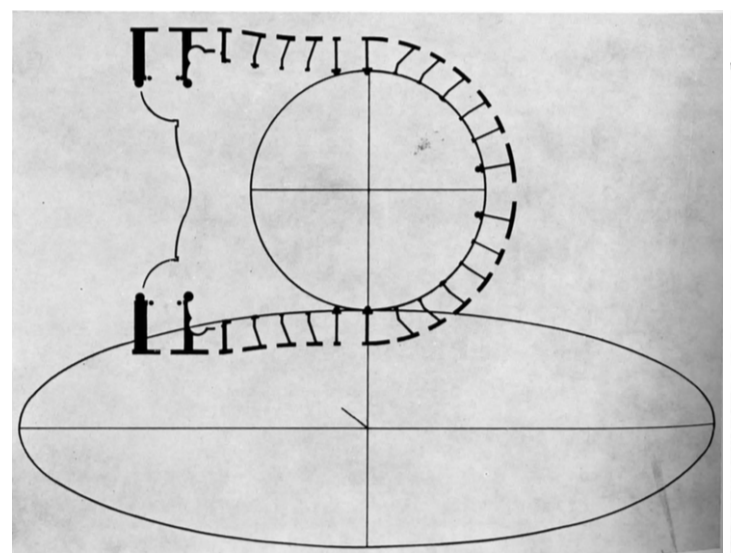

(a) Teatro Comunale in Bologna (1763)

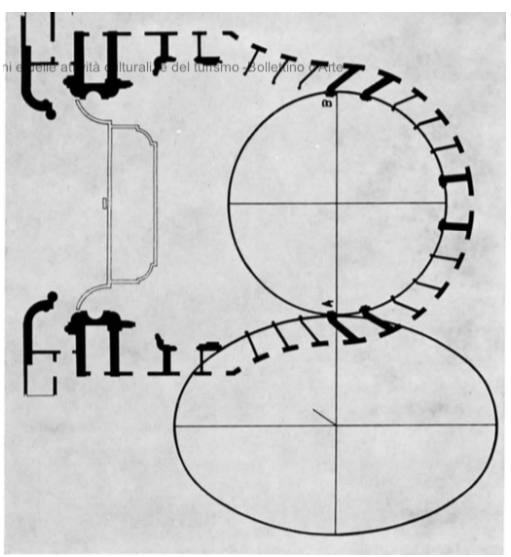

(b) Teatro Fraschini in Pavia (1773)

Figure 8. Plans of two bell-shaped theatres by Antonio Galli Bibbiena [53].

Algarotti agreed with some building techniques used by Galli Bibbiena, e.g., the mixed use of masonry and wood in the theatre: masonry for the bearing structure in order to prevent fire and timber for indoor cladding in order to "equalise" the sound. He proposed the use of timber as cladding, analysed the case of a room-considered as a finite volume-with different boundary conditions (walls, tapestries, timber). Moreover, he linked their effects both on the vocal timbre and on the sound level spatial decay. He also noted that a room with flat walls made the voice too "sharp", while a room covered by tapestry made the voice too "silent". Instead of this, a room cladded by timber made the voice loud and pleasant. Therefore, he stated that the all the wooden parts inside the theatre had to be aged. Building solutions of the Teatro Comunale in Bologna, built by Antonio Galli Bibiena in the same years of Algarotti's essay, reflected this approach. Moreover, Algarotti discussed about the 
maximum dimensions of a theatre, which should be limited taking into account the sound strength of the voice, quoting Vitrivius's fifth book [6]. Concerning the shape of the audience, Algarotti denied the bell-shape for sake of visibility, although it is ideal for the strength of the voice. He proposed the use of the elliptical shape, being the semicircular shape an ideal solution but unachievable due to the too large width of proscenium. Furthermore, he avoided the decorations with sharp elements, referring again to Vitruvius's dissonantes category. In order to optimise the hall volume, he also proposed that all the tiers of boxes had the same height: the architectural praxis was to increase the width of boxes in the higher tiers in order to emphasise the cavea perspective. Algarotti's essay was extensively quoted in the work by Antonio Planelli (1737-1803), titled Dell'opera in musica. Trattato del cavalier Antonio Planelli dell'ordine gerosolimitano (On the Musical Opera. Treaty by Knight Antonio Planelli of the Jerosolimitan Order, 1772), in the section related to the construction of theatres [54].

Another late 18th-Century author, who analysed the effects of boxes in Italian theatres, was Francesco Riccati (1718-1790) [55-58]. He compared the Italian theatre with the one developed in the European courts, characterised by open galleries, but he also pointed out the benefits, in terms of social connections, that the boxes ensured to their owners. In particular, he did not agree with the presence of not proportioned openings in theatre cavea, which was in contrast with the architectural rules and with an idea of harmony and elegance of the structure. According to Riccati, a theatre should satisfy at least two main requirements: it should ensure the possibility to see and to hear properly. In his book Della costruzione de' teatri secondo il costume d'Italia vale a dire divisi in piccole logge (About the Construction of Theatres According to the Italian Style, i.e., with Small Boxes, 1790) [55], he dealt with both such themes (The essay opens with the following words: "Fra tutte le produzioni dell'Architettura Civile la più disastrosa, la più difficile, la più contumace ad assoggettarsi alle teoriche della scienza, ed ai precetti dell'arte, ella, non v'ha dubbio, è la costruzione de' Teatri giusta il costume d'Italia" (Among all the outcomes of Civil Architecture, the most disastrous, the most difficult, the most insubordinate towards the theories of science, and the norms of art, it is, without doubt, the Italian construction of theatres).). First of all, he identified the curved shape as the best solution for the cavea because it allows for aligning a high number of boxes along the cavea itself, ensuring a sufficient visibility to all of them. Secondly, among the different kinds of curved shapes, he suggested the use of the "divergent" shapes. In fact, the adoption of a concave curve ensured the visibility of the stage to the major part of the public, especially if the part of the curve overlooking the proscenium was made as large as possible. According to the author, the horseshoe shape originated from the degeneration of this attempt. In particular, he disagreed with this particular shape as it enlarged the part of the curve facing the stage way too much, leading to the necessity of narrowing the part of the curve closer to the stage itself. In this way, the boxes located at the sides of the cavea were necessarily disadvantaged. An appropriate shape for the audience was, in Riccati's opinion, the bell shape, which was often adopted by the architects Galli Bibbiena in their theatres. Indeed, this shape could ensure a good visibility to the whole public. Riccati strongly criticised the use of the elliptical shape, which was instead proposed by Luigi Rizzetti (17??-18??), in a piece titled Memoria intorno alla più perfetta costruzione di un Teatro (Essay on the Most Perfect Construction of a Theatre) [59], quoted by Riccati in his treatise and later on published as the small pamphlet Risposta del sig. Conte Luigi Rizzetti alle accuse date al Teatro da lui proposto (Response to the Allegations Made to the Theatre He Proposed, 1792) [60]. Rizzetti's choice of this shape was probably due to a property of the ellipse: the rays coming from a focus reflect one another. For this reason, Rizzetti placed the stage border on a focus of the ellipse, thinking that it would support the sound diffusion. Riccati observed that the public sitting in the boxes at the stage sides would not be able to have comfortable visuals to it because it would directly face the other side of the cavea. Probably influenced by the political and social issues that revolved around the concept of an "ideal" theatre (see next paragraph), Riccati claimed that the best shape was the circular one, although it was possible to adopt it only in small theatres, otherwise the stage-which would have been placed on the diameter of the circle-would become too wide. 
Riccati thus proposed an elliptical shape obtained by different circle sectors. These sectors were drawn fixing the circle centre on the diameter of the wanted ellipse. In Figure 9, an ellipse is shown built up with three circular sectors (CF, FG, GD). The sectors CF and GD are drawn centering, respectively, the compasses on the points $\mathrm{N}$ and $\mathrm{O}$, located on the shorter diameter out of the ellipse perimeter. The sector FG is drawn centering the compasses on the longer diameter, on the point $\mathrm{E}$, located on the cross point of the segment NF and OG. The whole construction is ruled by the dimension of the segment BE. Increasing this dimension, it is possible to obtain an ellipse with a larger apex, which can contain a consistent amount of boxes facing the stage.

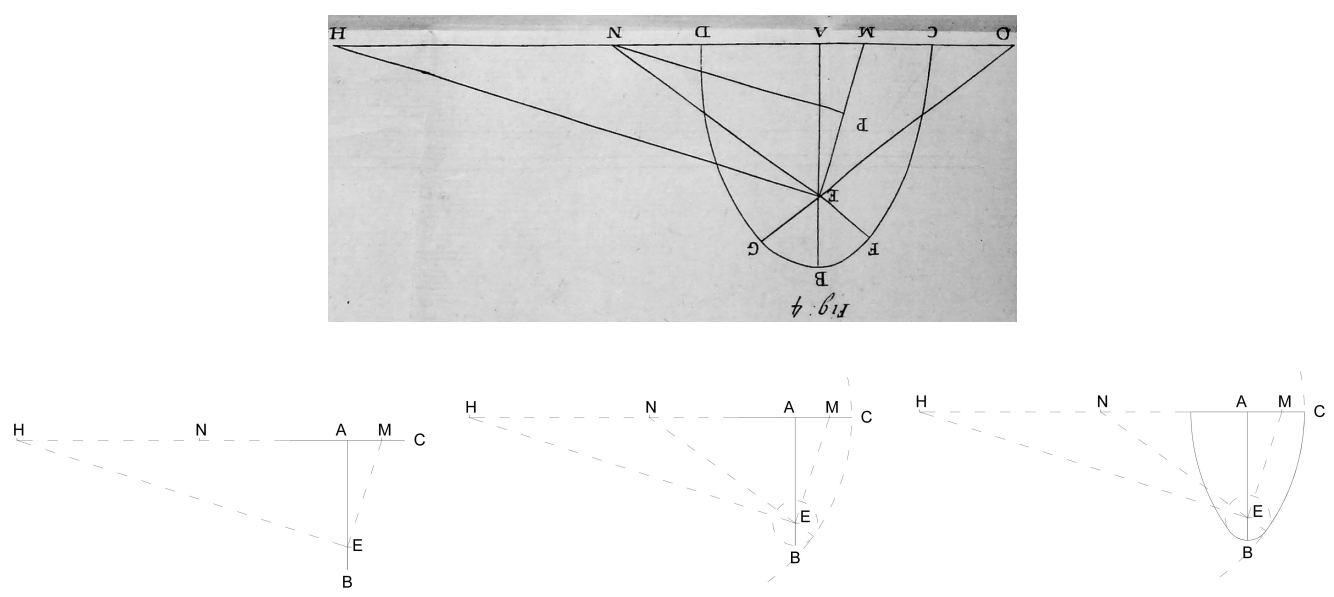

Figure 9. Francesco Riccati's guidelines to determine the elliptical shape of a theatre with circular sectors. Riccati's original drawing (1790) and re-drawings-more details are in the text.

The elliptic shape was used also by Cosimo Morelli (1732-1812) [61]; at the time, one of the most influential architects of the Papal States [62]. Due to visibility properties of elliptical shape, Morelli designed a three-part stage for the theatre of Imola (1780)—see Figure 10. He compared the width of the proscenium of an elliptic-shaped plan (segment GH in Figure 10) with that of the proscenium in the bell-shaped plan (segment EF) and the horse-shoe shaped one (segment DD). Indeed, the proscenium would be wider using the elliptical-shaped design. According to the architect, this configuration allowed also a larger stage for the scenes, a better visibility from the boxes, and a higher occupancy in the stalls. 

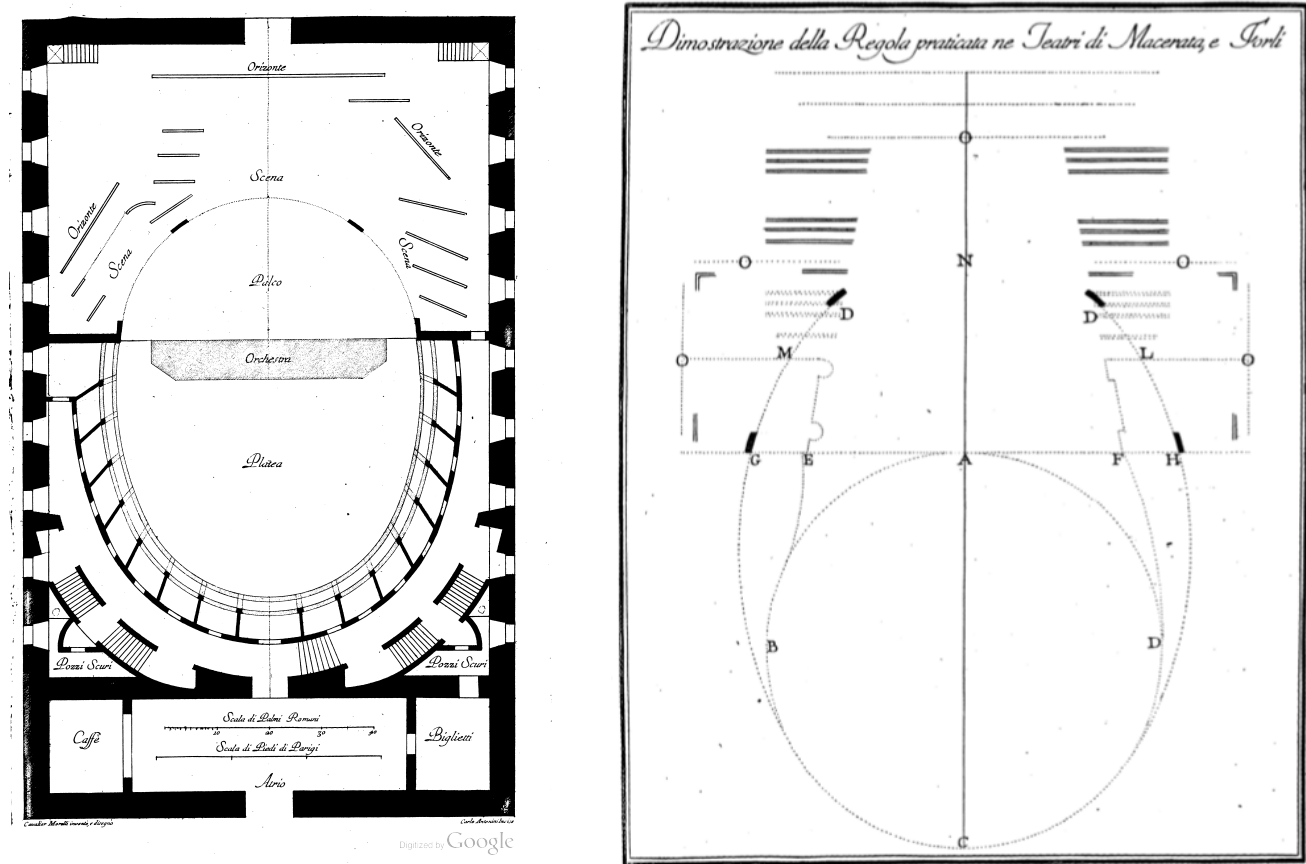

Figure 10. Plan of the Theatre in Imola designed by Cosimo Morelli [61].

The essay by the Venetian author and nobleman Andrea Memmo (1729-1793), titled "Semplici lumi tendenti a render cauti i soli interessati nel teatro da erigersi nella parocchia di S. Fantino in Venezia" (Simple Hints for Those Who Are Interested in the Theatre to Build in the Parish of S. Fantino in Venice, 1790) is an interesting account of the scientific knowledge on the theatrical construction in those years [63]. Far from the political and social ideologies that had been surrounding the idea of theatre in the second half of the 18th Century, Memmo focused on the building characteristics of a space for music and performances. He first pointed out the directivity of the sound sources. In his opinion, the Vitriuvian design of circular-shaped theatres was not optimised to the voice directivity, which decreases with the increase of the angle from the principal direction. Furthermore, the timbre of the voice depends both on the direct sound and the reverberated field. The author thus noted that reflected acoustic rays should converge to a central line and not to a point. In this case, a phenomenon of resonance (circumsonare) can be avoided. He focused on the necessity of balancing sound reflexion and diffusion, with the proper control of concave and convex shapes. At the same time, the direct and the reverberated fields had to be balanced: in particular, the latter could be equalised with a proper choice of the materials. In fact, Memmo was aware of the different acoustic absorption of porous and rigid materials, and he also referred to the problem of the different kinds of wood and their ageing. Furthermore, he stressed the importance of vaults made of light materials, in order to have low frequency absorption due to membrane-resonance effects. Quoting the essay of the Neapolitan engineer Vincenzo Lamberti (17??-18??), who dedicated his work to Memmo himself [64], Memmo referred to the bell shape-named pelcinona by Lamberti-as the optimal shape for a theatre. It is also interesting to notice that the author made no specific distinction between the acoustic and the lighting technique, which on the contrary were usually divided between the concerns of the physicists and those of the scenographers. By reading this essay, it is possible to claim that the technical and scientific knowledge around the building of theatres was extremely high in late 18th-Century publications, despite the lack of written works by the architects who were active in the field. This confirms the refined results by contemporary theatres, such as Teatro alla Scala in Milan (1776-1778) by Giuseppe Piermarini (1734-1808) and the already mentioned theatres by the architects Galli Bibbiena. A similar knowledge was established also by George Saunders (1762-1839), who wrote A Treatise on Theatres (1790) [65]. In this book, Saunders designed a theatre whose dimensions were based on audible 
threshold of a human voice and prescribed the use of wood in order to absorb the right amount of sound. Saunder's design of theatre was semicircular and showed some similarities with Enea Arnaldi's treatise (see the next section).

These last two sections have dealt with still existing Italian Opera houses, but it is important to keep in mind that several others were demolished or burned down. These events contributed, as stated in the Introduction, to a "Darwinian" evolutionary process of the optimisation of the shape and of the technical solutions of the theatres that were rebuilt after their demolition. For a complete chronology of the Opera houses of this period, see [66].

\section{The Ideal Theatre}

Throughout the 18th-Century, a widespread theoretical debate exploded on the social role of the theatre. Several French authors and theorists, such as Voltaire (1694-1778) and Diderot (1713-1784) [67] among the others [68-80], wrote on the educational importance of theatre performances. At the same time, the model of the classical, circular theatre was taken at the ultimate formal example [81,82], thus mirroring the necessity to erase the strict social division that characterised the partition between the audience and the boxes. Indeed, equality in listening and seeing had to match social and political equality, as a forerunner of the ideologies that led to the French Revolution. For a precise analysis of the connections between Italian theatres and French theoretical texts, see $[83,84]$. If in France the only architectural outcome of these theories was the theatre of Claude-Nicolas Ledoux (1736-1806) in Besançon (1775-1784) [81], these experimentations had no physical results in the Italian context. Nevertheless, architectural theorists like Enea Arnaldi (1716-1794) and Francesco Milizia (1725-1798) published on the topic of the "ideal theatre" and, most probably, they directly influenced some of the French designs $[83,84]$.

In 1762, the architect Enea Arnaldi published in Vicenza the essay titled L'idea di un teatro nelle principali sue parti simile a' teatri antichi all'uso moderno accomodato (The Idea of a Theatre Being Similar in its Parts to the Ancient Theatres and Adjusted to the Modern Use) [85]. His ideal theatre merged the characteristics of the ancient models-of Vitruvian origins-together with the Italian typology. In fact, he added a series of semi-circular steps to the audience and gave a cylindrical shape to the orchestra pit (see Figure 11).

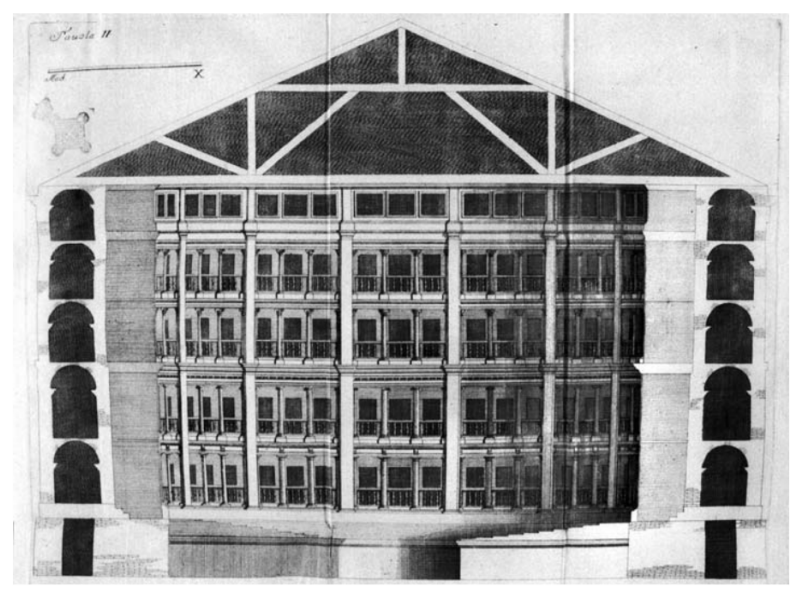

Figure 11. Section of the theatre proposed by Enea Arnaldi [85].

Shortly after, in 1773, the theorist Francesco Milizia wrote an essay about the Italian theatre [86]. He compared the so-called modern theatre with the ancient one, thus complaining about its degraded conditions. The author observed that modern theaters were built with flammable materials and they were affected by humidity problems, whereas the main features of such constructions were supposed to be robustness, comfort and convenience. Among all European theatres, he only mentioned as "solid" 
those of Turin, Naples, Bologna and Berlin. Examining the shape of the auditorium, Milizia also highlighted the inappropriate form adopted for the Italian theatre. He compared the semi-circular ancient theatre, where all the spectators were able to see and hear properly, with the shape of the modern theatre and its boxes, that did not allow satisfying visuals to the whole public. He wrote: "the geometry itself demonstrates that, in a circle, all the angles of the circumference, which have as their basis the same diameter, are equal" [86]. For this reason, the author recommended assuming a circular shape and to place the stage on the main diameter, as the only way to guarantee the same perspective on the performance to each person in the audience. In addition, Milizia criticised the presence of boxes, which, in his opinion, divided the volume of the theatre in too many small spaces. On this, he wrote that "the boxes cut and reverberate the resonant air", thus confusing the perceived sound. In order to strengthen the criticism of the modern theatre shape, Milizia necessarily quoted Vitruvius. In fact, the Latin author affirmed that the inclination of the ancient theatre was chosen following musical proportion and it permitted a visual contact between the listeners and the actors. On this issue, Milizia published the project of an ideal theatre, called Teatro Ideale (1773). Taking example from Arnaldi's theory, he designed a more radical project, introducing French revolutionary themes into theatre design. In the Teatro Ideale, the architect replaced the separated boxes, reminders of the class divisions, with open galleries. The ideal theatre was characterised by a semi-circular shape, semi-circular ceiling, cavities and resonators, and galleries. On one hand, Milizia's assumptions were not acoustically appropriate and this was shown by the numerical simulation of the Teatro Ideale, realised from the original drawings [12]. In fact, considering the overall values of the acoustic descriptors the Teatro Ideale appears as a reverberant theatre- $T_{30}=2.6 \mathrm{~s}$ at $1000 \mathrm{~Hz}$ in unoccupied conditions-more than the existing Italian theatres of that period $[15,19,20]$. On the other hand, Milizia's theoretical contribution was extremely important when it comes to the social role of the theatre, which was seen as a public space. Indeed, his struggle for a more democratic spatial configuration of the audience could be seen as a forerunner of Richard Wagner (1813-1883) and his "democratisation of acoustics" [87]. While the 18th-Century theatre was still a place for aristocracy, Milizia saw in theatre performances a means to convey the social image of a more equal and educated society, able to mirror the idea of a nation—-the Italian one-still scattered into different states (see Figure 12). 


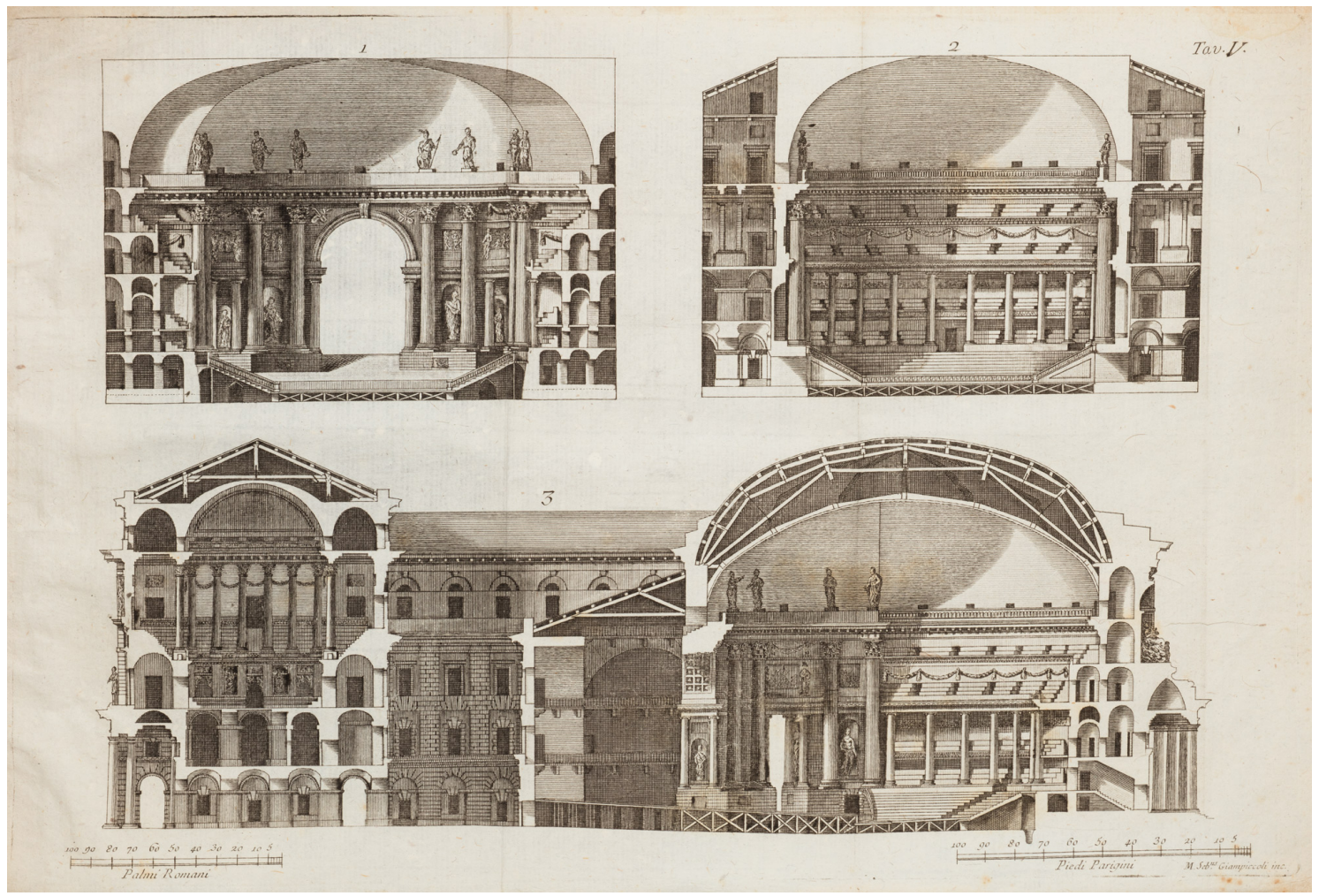

Figure 12. Design of the "Ideal Theatre" by Francesco Milizia and Vincenzo Ferrarese [86].

Milizia's writings strongly influenced the work of the architect Giovanni Antonio Antolini (1753-1841) who designed the grand "Foro Bonaparte" (1801) in Milan, in the area surrounding the Sforza Castle. Within the unbuilt architectural complex of the "Foro", Antolini introduced Milizia-Ferrarese circular-shaped theatre—that he named the "school for morals" [88]—equally divided between the stage and the semi-circular steps for the audience (see Figure 13).

Another follower of Milizia's theories was Tommaso Carlo Beccega (17??-18??), who published in 1817 an essay titled Sull'architettura greco-romana applicata alla costruzione del teatro moderno italiano e sulle macchine teatrali (On the Application of the Graeco-Roman Architecture to the Construction of the Modern Italian Theatre and to the Theatrical Machines) [89]. The basis of this essay was Vitruvius's theory and, at the same time, he tried to develop a theatre standard, whose shape was a semi-circle with elongated extremities (see Figure 14). Recalling the Vitruvian principle of comfort, he deducted the stage inclination, the orchestra pit position-lower than audience in the stalls-the proscenium arch shape and proportion, the construction of the dividers between boxes. He also claimed that the theatre height should have been equal to the cavea width, in order to avoid excessively deep halls. He fixed the maximal length of the audience, which should not exceed $45 \mathrm{~m}$, the recognized audibility threshold. 


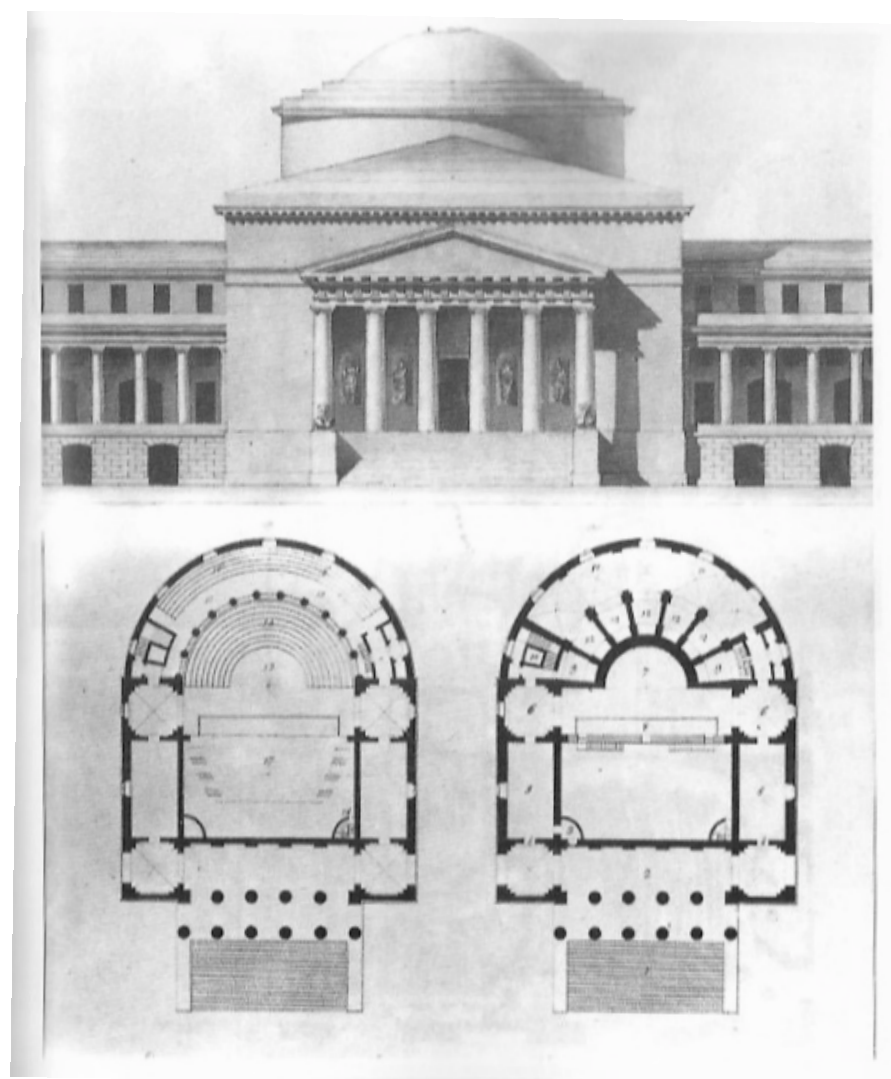

Figure 13. Giovanni Antonio Antolini's design of a theatre in the Foro Bonaparte in Milan (after [83]).

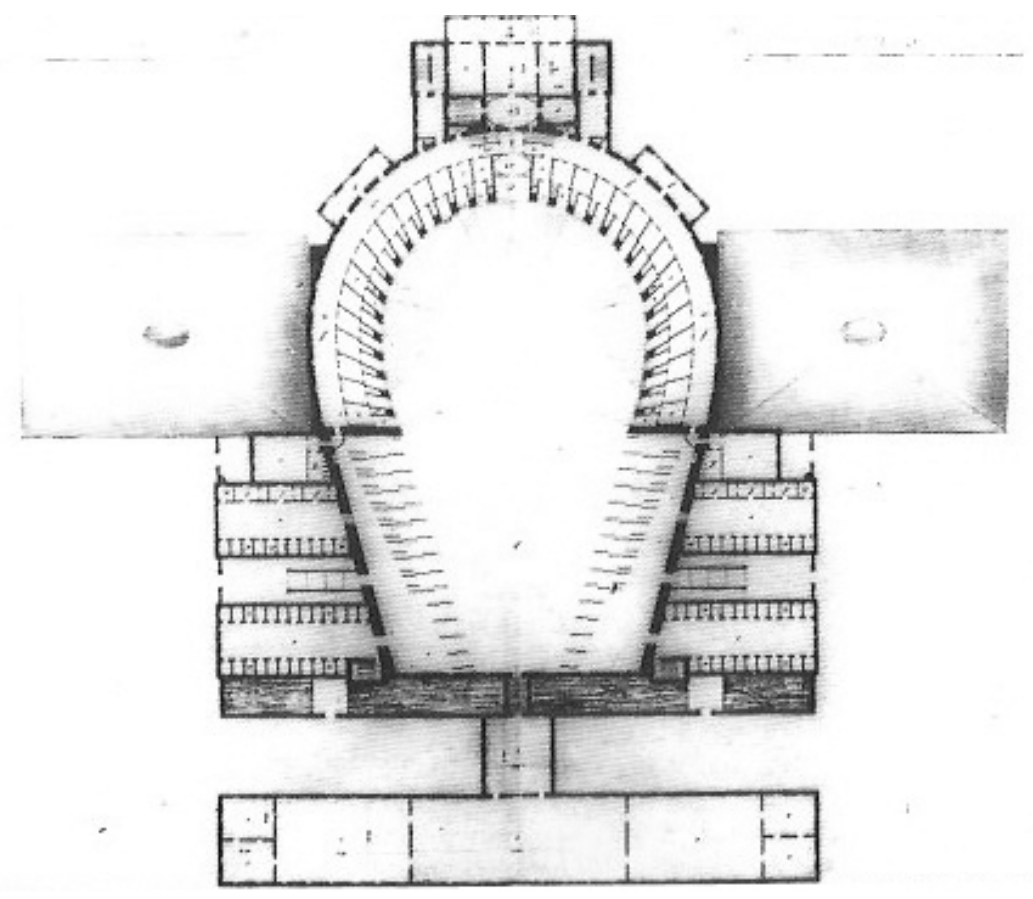

Figure 14. Ideal theatre shape according to Tommaso Carlo Beccega (1817) (after [83]).

\section{The 19th-Century Theatre}

The evolution of the 18th-Century into the 19th-Century theatre has not been diffusely discussed in architectural essays. However, it is clear that the theaters built during the 19th Century presented 
similar characteristics to the buildings belonging to the preceding century. By the mid-19th Century, the form of theatre was standardised and the vast majority of Italian opera houses was built after this period, in order to satisfy the request of each small town to have its theatre and the request of bigger cities to build increasingly larger ones.

At the beginning of the 19th Century, Antonio Niccolini (1772-1850) published a pamphlet entitled Alcune idee sulla risonanza del teatro (Some Ideas on Theatre Resonance) [90], in which he attributed the theatre deafness to its proportions and, exactly as Milizia did, to the use the boxes [83]. Differently from Milizia, Niccolini understood that the modern theatre characteristics derived from social and economical needs; therefore, he elaborated solutions in order to improve the acoustic of these theatres, taking into account the circumstantial necessities. Niccolini's research followed a completely different path than those of his predecessors: he investigated the stage dimensions-and compared to the dimensions of the audience-and the vault continuity as deafness causes. In his opinion, the shape of the theatre and the used materials were irrelevant. The first element significantly contributing to the theatre resonance was a wide stage opening, which conveyed an air flow from the stage area to the audience (see the Niccolini's plan of Teatro San Carlo in Figure 15)—where the air was more rarefied because of the presence of public - thus reinforcing the sound propagation. The second element was the vault which in his opinion should ensure the uniformity of the sound path.

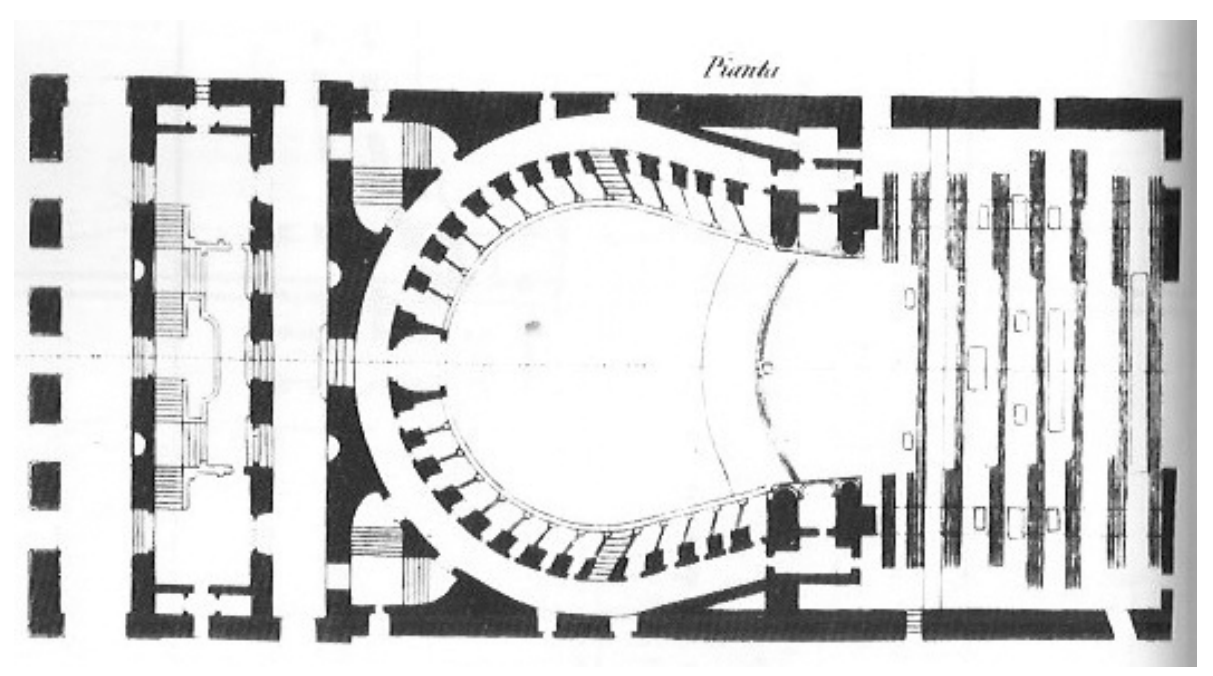

Figure 15. Antonio Niccolini's design of San Carlo theatre in Naples (1816) [90].

The architect and scenic painter Paolo Landriani (1757-1839), in his Osservazioni sui difetti prodotti nei teatri dalla cattiva costruzione del palco scenico e su alcune inavvertenze nel dipingere le decorazioni (Observations on the Flaws Deriving by the Poor Construction of the Stage and on Some Oversights in Decoration Paintings) [91], provided a description of a common method used to determine the theatre shape in that period. The usual shape adopted for theatres was a curve composed by a semi-circle and two lines, with a focal point at a distance of two diameters of the aforementioned semi-circle. The whole length of the theatre was usually similar to the length of the circle diameter; the proscenium width was determined by the intersection of the aforementioned lines with a line tangent to the circle. It could also happen that the length of the audience was longer than the circle diameter: therefore, the proscenium width could be determined as explained in Figure 16. It was the author's firm belief that the acoustic quality of a theatre depended on: the horseshoe shape commonly adopted; the lack of interruption or projections in the cavea boundary; the wooden parapets of the boxes; the elliptical vault above the audience, which should be as flat as possible; the proscenium opening, which should be wider on the audience side; a slightly inclination of the proscenium arch ceiling towards the stage, so that the actors' voices could spread easily into the auditorium as a ray. 

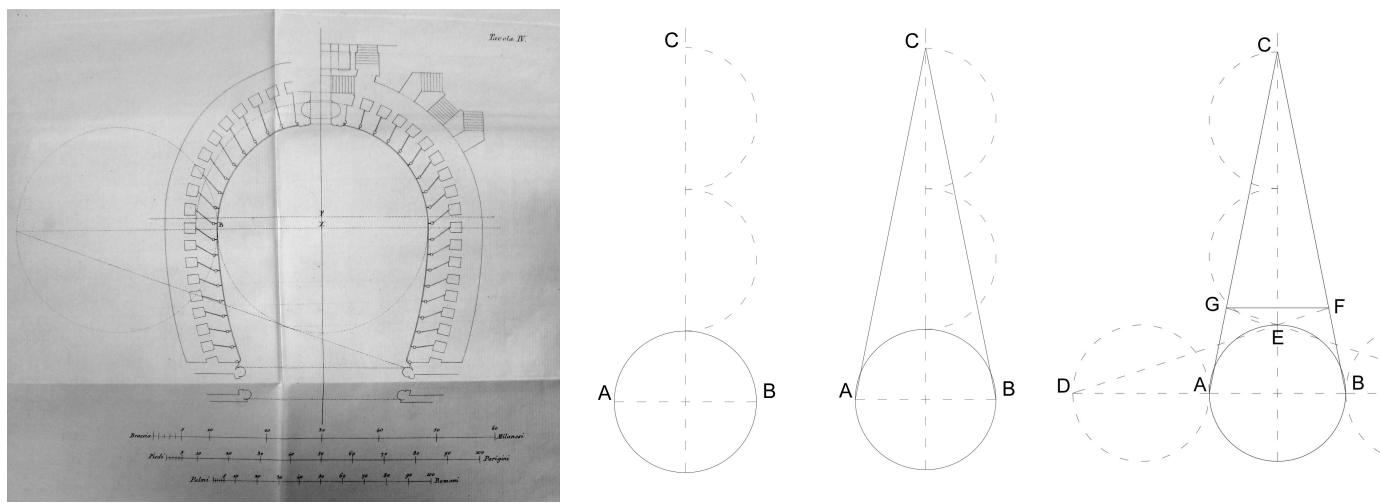

Figure 16. Paolo Landriani's guidelines to determine the proscenium width. Landriani's original drawing (1828) and redrawings [50]. See details in the text.

As stated before, theatres were prone to fires and therefore they were often rebuilt. Just like Niccolini, also the Venetian architect Giovanni Battista Meduna (1800-1886) and his brother Tommaso (1798-1880) had to deal with the reconstruction of a theatre. In their case, they rebuilt the theatre La Fenice in Venice, already debated by Memmo in his essay: the theatre was destroyed by fire in 1836 and it was reopened in 1837 [92]. Meduna's method is still "classic", regarding both the shape of the hall and the use of the materials. In particular, the Meduna brothers used the properties of timber in order to create resonant volumes under the stalls [93].

Already in the first decades of the 19th Century, the shape and the building techniques for theatre construction were almost consolidated: therefore, contemporary scholars focused on manuals or historical overviews [94-97], which progressively accounted for a theatre form with standard shapes and building typologies. It is not a coincidence if, in the same years, some Italian composers-such as Gaetano Donizetti (1791-1848), Vincenzo Bellini (1801-1835) and Giuseppe Verdi (1813-1901)—wrote some of the most iconic Italian operas [98]. The popular fame of these operas is strongly connected to the need of building theatres in every town, thus "scaling" the geometries on reduced volumes and occupancy [16-18].

From the second half of the 19th Century onwards, there was a progressive change in the building typologies of theatres. For example, the use of steel (such as in the Politeama theatre in Palermo, designed and built between 1865 and 1891) [99] and the use of cast-iron in the bearing structures, thus replacing timber or masonry, had resulting effects on the acoustic of such spaces [100,101].

The last moment in which Italian Opera houses were extensively built can be located in time just before the arrival of cinema. In those years, some great Sicilian theatres were built: like the Bellini theatre in Catania (inaugurated in 1890) and the Massimo theatre in Palermo (inaugurated in 1897), which is still today the biggest theatre of the Italian peninsula [102,103]. These last theatres were deeply influenced by geometries and spatial schemes that could not be described as merely Italian anymore, but "European", as they were affected by French (Opéra Garnier, 1875) and Austro-Hungarian (Wiener Staatsoper, 1869) designs. In fact, they do not only show boxes, but also galleries; they have large foyers that could host the new bourgeoisie, together with the high classes.

A reverse exemple- - that is, an Italian architect working in an European architectural background, as the architects Galli Bibbiena had done in the former Century-was the architect Antonio Canoppi (1769-1832). In 1830, he published his Opinion d'A.C. sur l'architecture en général et en spécialité sur la construction des théatres modernes (The Opinion of A.C. on Architecture in General and in Particular on the Construction of Modern Theatres) [104]. He was an Italian architect who had been working in Russia since 1805 as theatre director for the Russian Empire. He designed two theatres in St. Petersburg (see Figure 17), whose occupancy were, respectively, of 2200 and 1000 people. Thanks to studies on optics, perspective and acoustics, he fixed the length of the cavea-in the larger theatre-at 
$25.8 \mathrm{~m}$ and the proscenium width at $12.9 \mathrm{~m}$. The dimensions of the stage were very large, in order to host monumental scenographies.

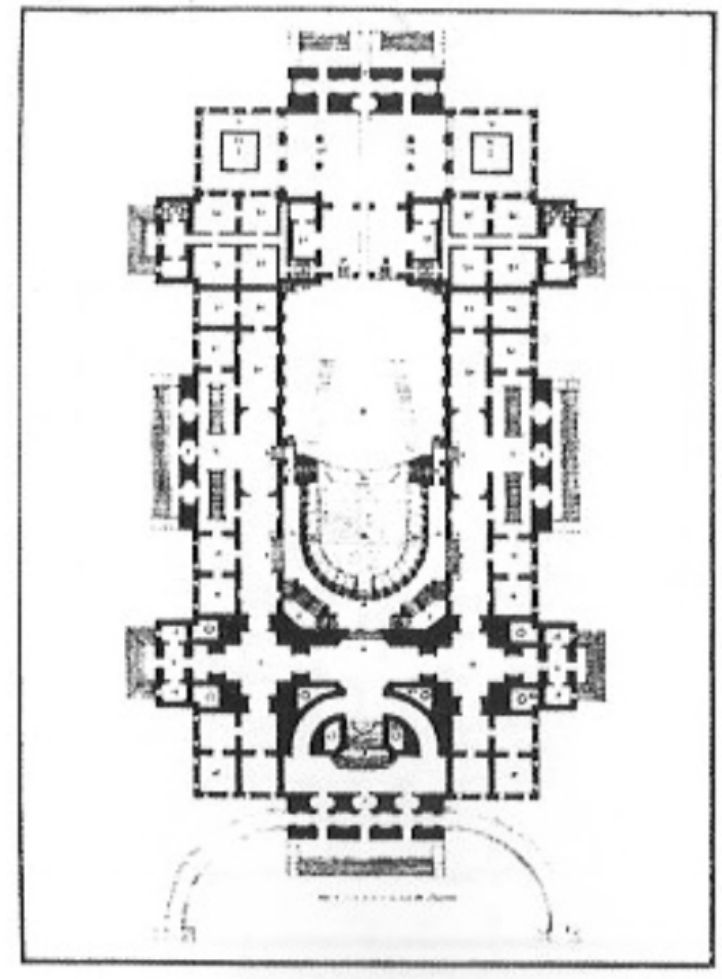

(a)large-sized theatre

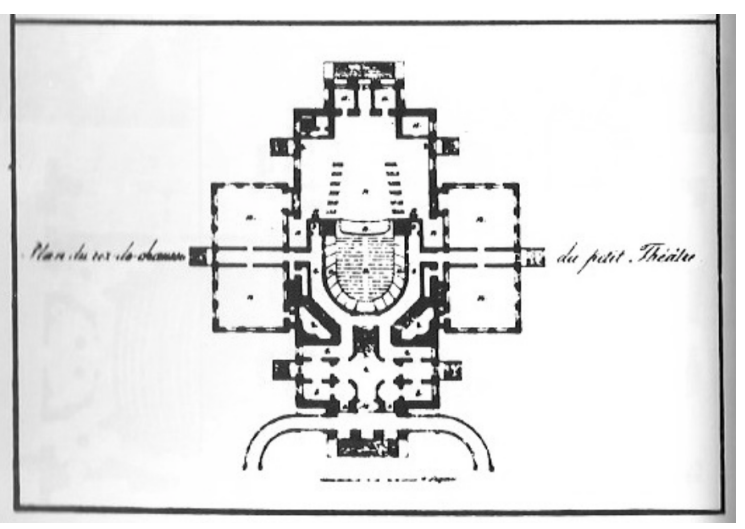

(b) small-sized theatre

Figure 17. Antonio Canoppi's drawings of two theatres in St. Petersburg (after [83]).

In order to better understand the chronological evolution of each hall shape, together with their analysis in literature, Figure 18 represents a timeline overlapping the construction year and shape of each mentioned theatre, together with the life spans of the debated authors. 


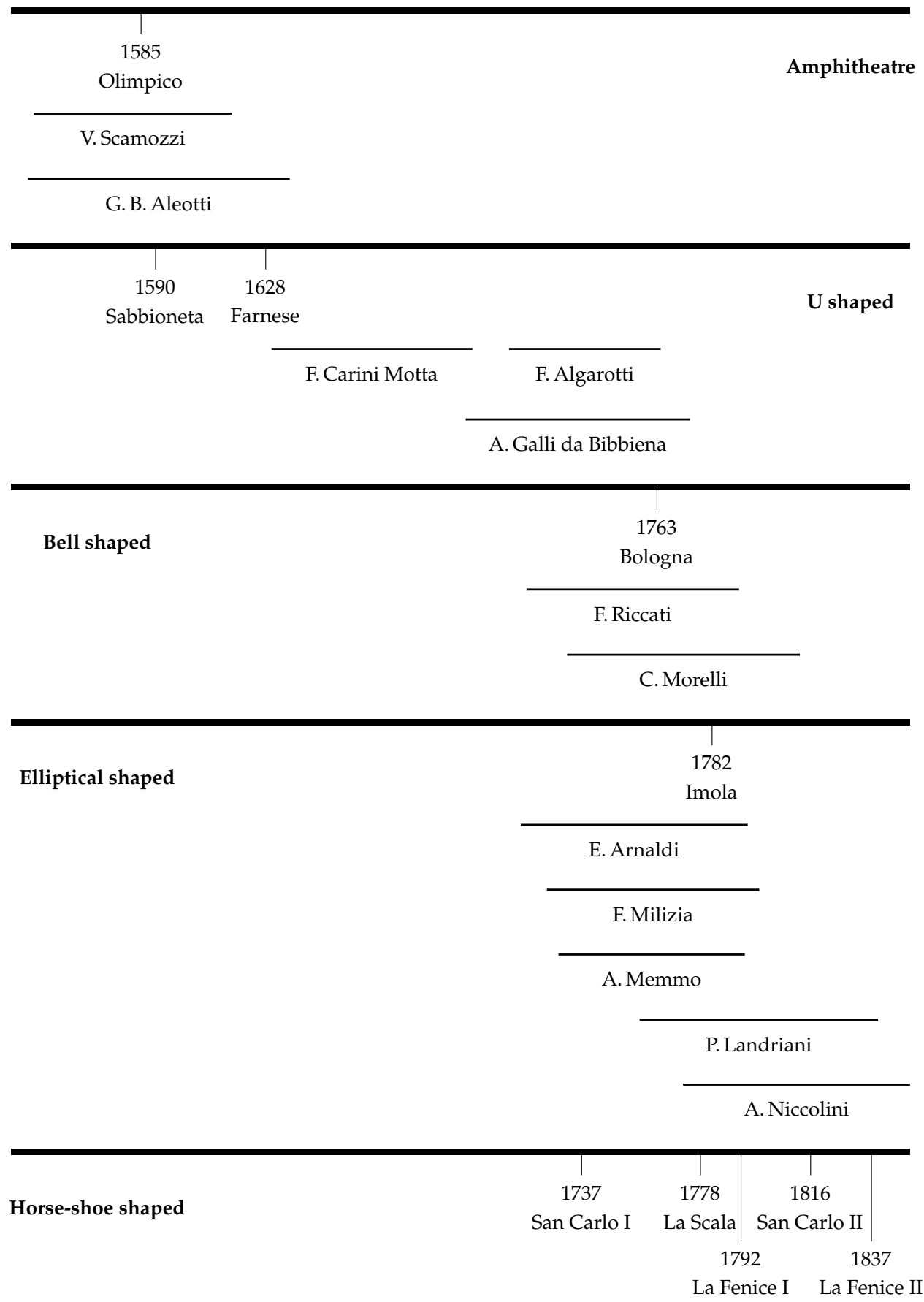

Figure 18. Evolution during time of the different shapes for Opera houses. In particular, some of theatres mentioned in the text have been marked on each timeline, together with the life span of mentioned authors.

\section{Evidences in Small-Sized Theatres of the 19th Century}

Five small-sized Italian Opera houses have been selected as case studies because of their similar dimensions and social function. All of these theatres were designed and built in the 19th Century: Municipal Theatre of Cervia (CER), Municipal Theatre of Cesenatico (CES), Municipal theatre of Russi (RUS), Dragoni theatre of Meldola (DRA), Petrella Theatre of Longiano (PET); see further details in Table 1. Such theatres were chosen due to the availability of the original designs in the city 
archives (see Figure 19) and a complete documentation about the restoration works of the last several decades [36,105-112].

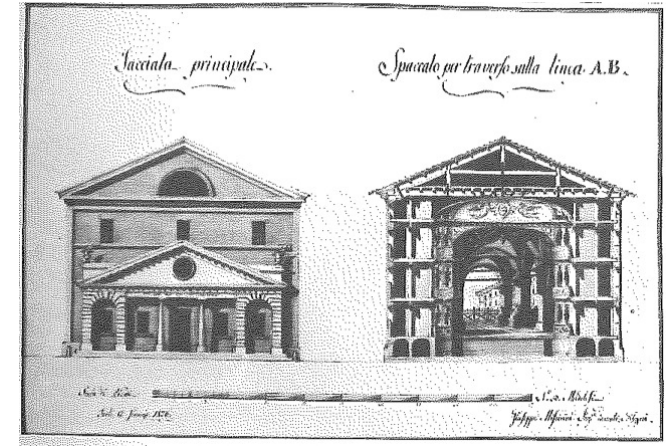

(a) DRA

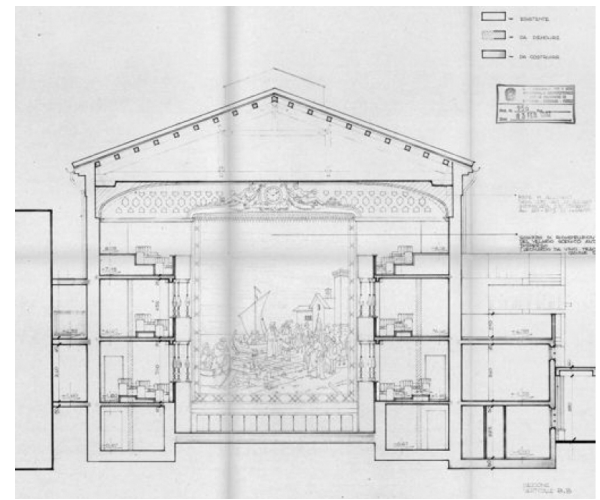

(c) CES

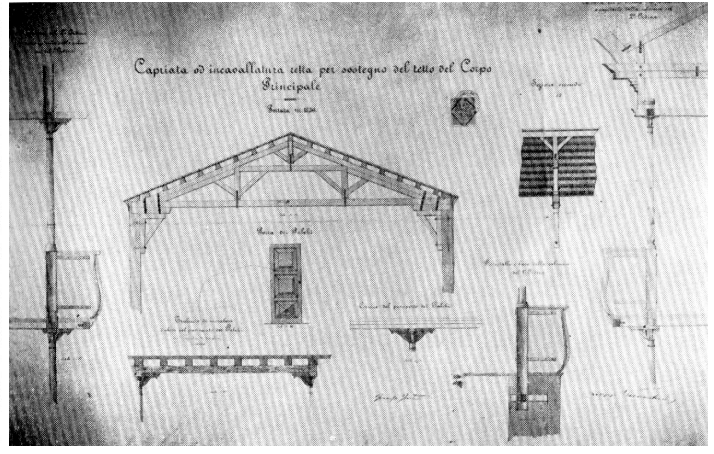

(b) RUS

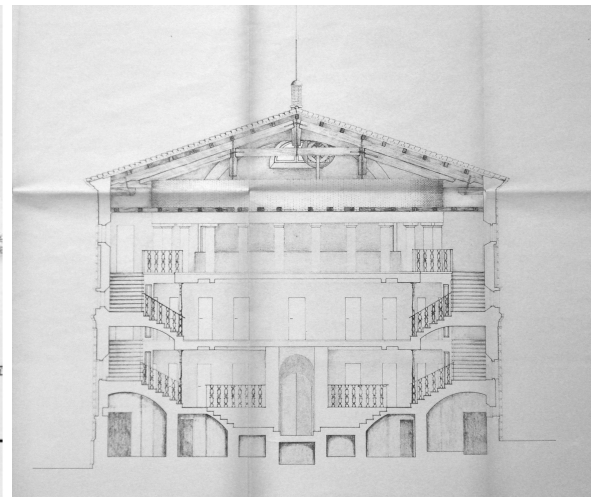

(d) PET

Figure 19. Some original drawings of the small-sized opera houses under study. Such drawings are available at the local city archives and local publications [36,105-112] and represent one of the key sources for the historical research on such buildings, collected in [50].

Table 1. Architectural features of the small Italian historical Opera houses under study. $T_{30, M}$ is the measured value of Reverberation time at mid-frequencies averaged over the whole audience. Other measured room criteria are fully available on [19].

\begin{tabular}{lccccccc}
\hline & Theater, City & Seats & $V_{\text {hall }}$ & $V_{\text {stage }}$ & Scenic Arch & $T_{\mathbf{3 0 , M}}(\mathbf{s})$ & year \\
\hline DRA & Dragoni, Meldola & 318 & 1140 & 1080 & $6.8 \times 7.3$ & 0.83 & 1838 \\
RUS & Comunale, Russi & 305 & 900 & 1370 & $8 \times 7.5$ & 0.97 & 1887 \\
CES & Comunale, Cesenatico & 271 & 870 & 1320 & $7.4 \times 8.6$ & 0.90 & 1865 \\
CER & Comunale, Cervia & 224 & 730 & 1140 & $8.1 \times 7.4$ & 0.84 & 1862 \\
PET & Petrella, Longiano & 241 & 630 & 1390 & $7.5 \times 9.1$ & 1.07 & 1870 \\
\hline
\end{tabular}

A subset of these theatres can be made considering their shape: for example, CES and MEL show an elongated shape. Nevertheless, the two theatres show a significant difference, as CES has two boxes included in the proscenium arch (one on each side). Its shape is thus characterised by a linear part linked with the horseshoe shape. Among the others, CER and RUS show exactly the same bending. PET, instead, is very similar in its bottom part, even if it is smaller than the other two, but with a linear evolution closer to the stage. Considering the stage area, all theatres show more or less a rectangular shape, with the same irregularity due to the presence of service rooms. CER is an exception: because of urban necessities, the stage area is characterised by a strong asymmetry and the rear wall of the stage is not parallel to the proscenium arch. 
The aforementioned guidelines by Carini Motta, for the design of horse-shoe theatres, may be applied to these case studies. Following the author's instructions, an elongated shape with a linear part close to the proscenium arch can be obtained: therefore, this method has been applied to the theatres of CES and DRA, which present similar features Figure 20. The shape obtained following Carini Motta's method, with the dimensions of CES, is an offset of the real curve defining the audience boundary of the theatre. Considering the dimensions of DRA, the shape obtained is only a little too rounded on the sides of the audience, but, in general, it corresponds quite well to the real theatre shape. It also tried to apply Carini Motta's method to a different geometry, such as CER, yet with unsatisfactory results.

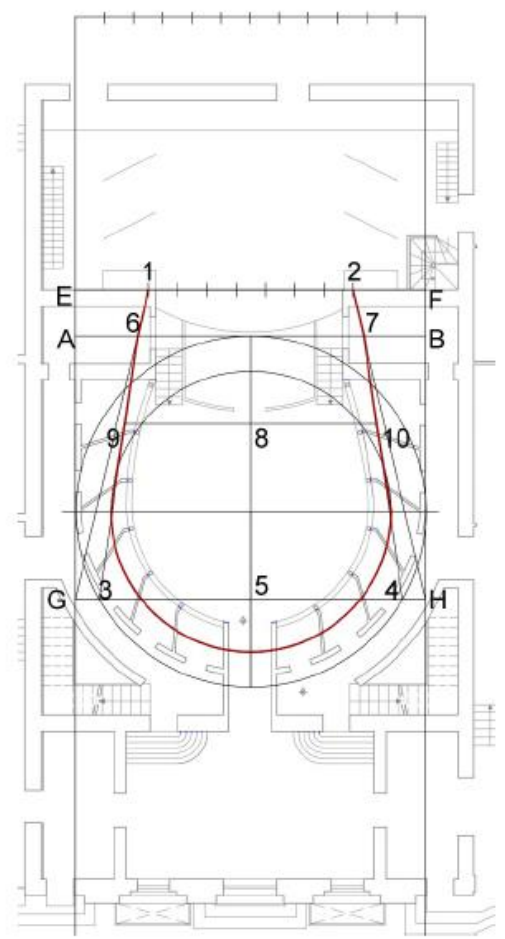

(a) CES

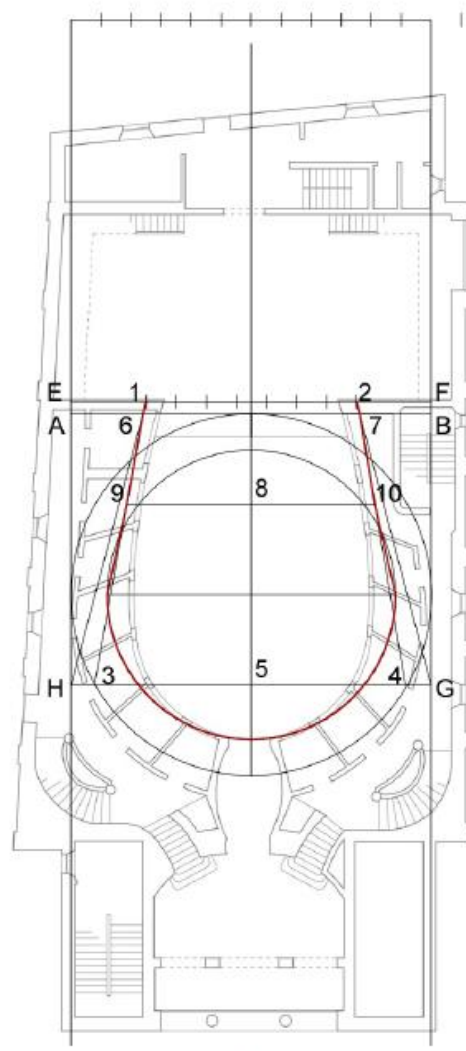

(b) DRA

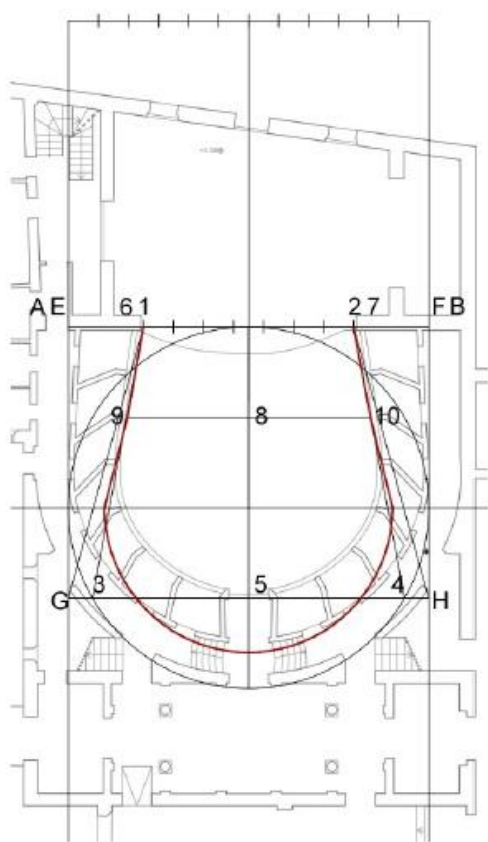

(c) CER

Figure 20. Attempts to apply Carini Motta's guidelines for drawing horseshoe-shaped theatres.

In Figure 21, Landriani's method to design the proscenium arch was applied to the small-sized theatres under study. This method has been first applied to the theatres with a more rounded shape, such as CER and RUS. For both theatres, the shape obtained is quite close-fitting to the real one. However, Landriani's method to define the proscenium arch width did not give satisfying results. The figures of CER and RUS show that the shape obtained following Landriani's guidelines is bigger if compared to the boundary of CER audience, while it is a bit smaller in the part close to the stage in the case of RUS. This means that RUS is defined by a more rounded shape. The same method was also applied to the theatres with a more elongated shape (that is, DRA, CES, PET). In DRA, the shape obtained fits quite well with the rear part of the audience, but it becomes too narrow close to the stage. The same observation also counts for PET; instead, Landriani's method applied to CES produced a tight-fitting shape. As for the theatres of CER and RUS, Landriani's instructions to define the proscenium arch width did not give satisying results. 


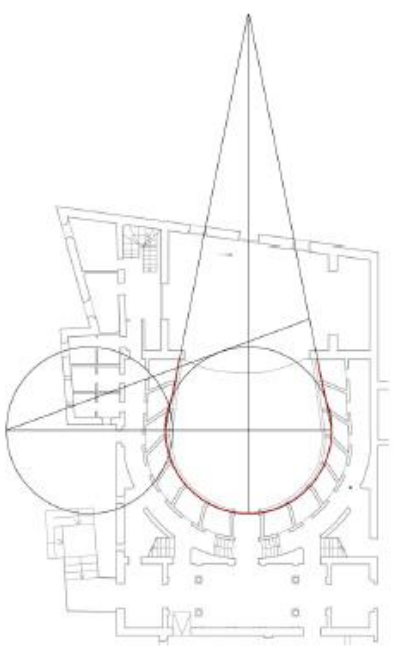

(a) CER

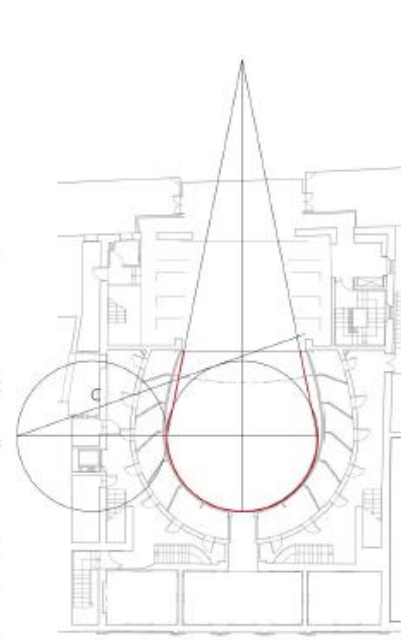

(b) RUS

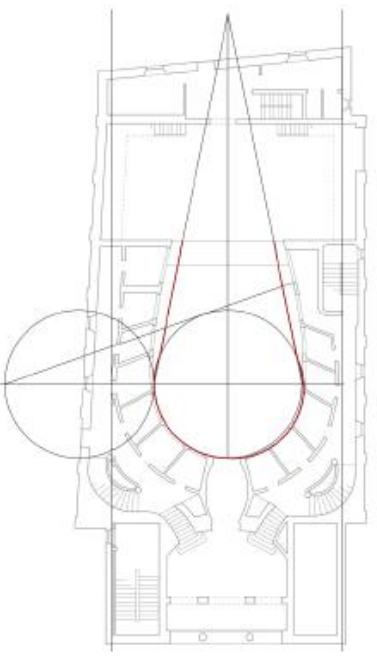

(c) DRA

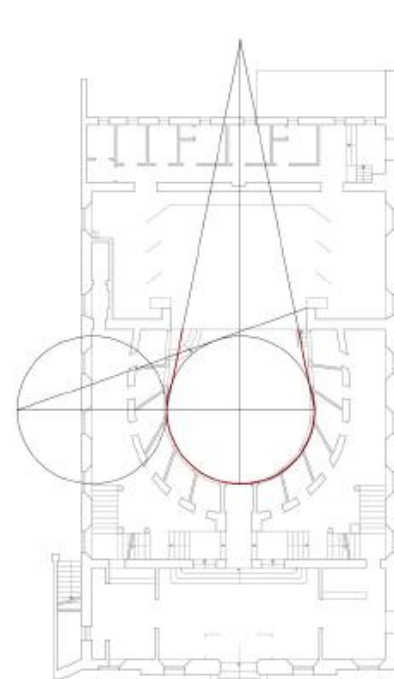

(d) PET

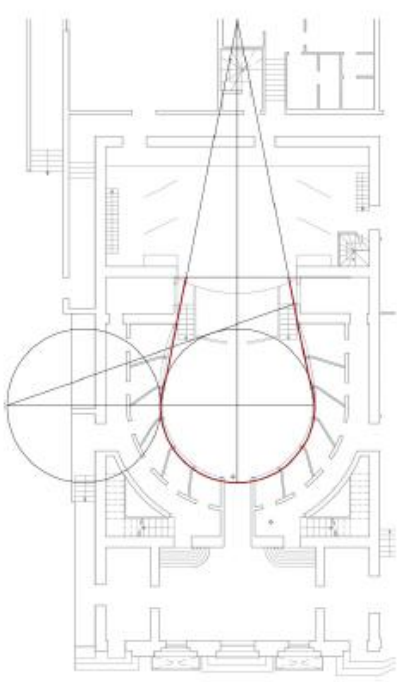

(e) CES

Figure 21. Application of Paolo Landriani's guidelines for dimensioning the proscenium width.

Such design features may influence the acoustic criterion of the hall. Despite of refurbishment differences in each theatres-changes in velvet, chairs and other elements and materials-the acoustic behaviour at the present day may still be dependent from design. The theatres under study were measured in a previous campaign of theatres in Romagna [19]. The positions of the omnidirectional sound source [113] on the stage were chosen similarly in all theatres: the first position on the longitudinal axis of the stage at $1 \mathrm{~m}$ from the edge (fore-stage); the second one at the centre of the area closed by the curtains (centre-stage). ISO 3382 [114] criteria were extracted from the measured impulse responses [115].

The values of reverberation time are quite low, if compared with other Italian Opera houses of bigger dimensions-swinging between $1.2 \mathrm{~s}$ (La Scala Theatre in Milan), those classified as "type B" by Prodi et al. [20], and 1.7s (Teatro Comunale in Bologna), those classified as "type A". As the reverberation time appears to be quite constant on all the audience, due to the complex connection between geometry and positions, it may be more useful to analyse a value that depends on the positions of the source and the receiver, such as the sound strength [114].

Table 2 summarises the measured values of $\mathrm{G}_{\mathrm{M}}$, using the two source positions described above (one in the proscenium and one at the centre of the stage), and also the averaged values on all the 
receivers of the same categories (all positions in the stalls, boxes and galleries). In general, results show how the position of the soloist on the stage influences the sound strength in the audience. $G_{M}$ values in the fore-stage are higher that the ones in the centre-stage. This may be due to the higher acoustic coupling when the soloist is placed in the fore-stage. This situation was well known by Opera authors, who often stressed in their librettos the right place of each aria, in order to balance the sound level of each soloist, the choir and the orchestra [87].

Table 2. Measured values of Sound Strength at mid-frequencies $\mathrm{G}_{\mathrm{M}}$ in the theatres under study (dB).

\begin{tabular}{cccccccc}
\hline Sources: & \multicolumn{3}{c}{ Proscenium } & & \multicolumn{3}{c}{ Center-Stage } \\
\cline { 2 - 4 } Receivers: & Stalls & Boxes & Gallery & & Stalls & Boxes & Gallery \\
\hline DRA & 10.2 & 7.3 & 5.5 & & 8.1 & 6.2 & 4.5 \\
RUS & 11.0 & 8.6 & 7.3 & & 8.7 & 7.4 & 6.8 \\
CES & 11.4 & 9.7 & 9.4 & & 9.3 & 8.4 & 8.4 \\
CER & 16.0 & 12 & 12.8 & & 13.0 & 12.0 & 11.9 \\
PET & 15.7 & 10.4 & 11.5 & & 11.8 & 9.0 & 10.3 \\
\hline
\end{tabular}

The use of a velvet band within the cavea of DRA-introduced by the renovation works of 1970s [36,105,108] - is for sure the cause of a low G value in the stalls. However, in this theatre, the shape factor of the hall is different from the others, as DRA is much higher than what the cavea surface would allow. This influences a low $G$ value in the gallery.

CER and CES, as stated above, are very similar. The choice of drawing the stage further back, in $\mathrm{CES}$, in order to insert a small orchestra pit, has a negative influence on the sound strength (about $3 \mathrm{~dB}$ are lost, for each couple source-receiver). In CES, the presence of the original design for the proscenium shows a sound strength homogeneity in the audience. In fact, apart from the values in the stalls for a source on the proscenium, that are necessarily influenced by its proximity, $G$ values are more or less constant in all audience, gallery included. This behaviour mirrors the scope of a good design of a theatre built for a community, which is a city theatre.

If RUS is too wide if compared to Landriani's method, PET fits perfectly into these guidelines. The latter was restored by preserving the original materials, as the former was renovated into a small contemporary prose theatre. PET also shows a great result of acoustic coupling between the fly tower and the cavea. G values are constant, with the exception of those in the stalls, due to the proximity effect.

To conclude, the measures of sound strength and its spatial distribution show that the design of a theatre hall is mainly based on the shape of the theatre itself, more than on the materials used (this is valid for small-sized Opera houses with a horseshoe shape, such as the aforementioned case studies). Restoration works may influence negatively on the acoustic behaviour of the halls, yet the influence of the original design still plays an important role.

\section{Conclusions}

This study had the aim of summarising the copious literature on theatre design related to pre-Sabinian scholars, from the 15th- and 16th-Century rediscovery of Vitruvius's treatise to 19th-Century standardised applications of guidelines and instructions by several Italian authors. The aim was to draw evidence of such literature in the design of Italian Opera houses, with a particular attention to small-sized Opera houses to be found in minor Italian towns.

In a contemporary acoustic point of view, the pre-Sabinian Italian scholars pointed out all the critical aspects of theatre design: Aleotti the relevance of the scenic arch [9], Carini-Motta [48] the separation of the acoustic volumes of the stage and the audience, Milizia [86] the coupling of the boxes, Riccati [55] the homogeneity of direct sound to the listeners, Rizzetti [60] the diffusion of the sound, Niccolini [90] the energetic transmission between stage and cavea and the relationship between reverberation and acoustic mean free path, and Beccega [89] the geometric ratios of the theatre and the 
echo-flutter phenomena. The dualism optics-acoustics might have often been useful to these authors, the knowledge in optics at the times being more advanced than that in acoustics.

Some of the topics that emerged from this study are at the core of the acoustic properties of Italian Opera houses. The majority of existent and active Italian theatres was bult between 1750 and 1880 and is characterised, for example, by a vast use of timber, whose effects have only partially been studied so far. Recent renovation works and the adaptation to fire-escape regulations have reduced the occupancy of such theatres. Moreover, their acoustic quality does not mirror the acoustic conditions at the time of their construction and full functionality in the 19th Century. In the authors' opinion, this may not necessarily be seen as a problem as the theatre has always been a flexible building, adaptable to the changes of the audience and to the functional necessities of the performances. The knowledge of such literature could instead be of help in the case of refurbishment of a historical theatre or of a new building with new materials, which still aims at preserving the acoustic characteristics of Italian Opera houses.

The birth of architectural acoustics as an independent science dates back to Wallace Clement Sabine's work. Interestingly, some Vitruvian categories were still used by Sabine himself [1], regarding speech intelligibility. Nevertheless, some of the main issues of architectural acoustics had already been consciously tackled by pre-Sabinian Italian scholars in their treatises. Although the concept of reverberation was not explicitly known, this literature shows a particular attention to the effects of materials, related to both intelligibility and abatement. In fact, timber was used not only for its ability to radiate sound energy (the analogy with the musical instruments is often recalled), but also for its capacity of absorbing part of the sound energy and thus equalising the sound. Moreover, issues related to the echo-flutter were tackled, both focusing on the elliptical shape and on the maximum dimensions of the hall. Furthermore, the Italian Opera house is a system of acoustic coupling of volumes. The fly tower was born for scenographic reasons-it is missing in the first performance spaces, but it soon became a critical element for the correct acoustic coupling of sound sources on the stage. On one hand, the fly tower cannot be too big for scenographic issues; on the other hand, some geometries like the bell and the ellipse enlarge the dimension of the scenic arch in order to host a sufficient number of people in the audience. This need is perhaps the reason why the horseshoe-shape eventually took hold.

To conclude, by quoting one of the authors analysed in the paper, this sentence by Antonio Niccolini-designer of the new hall of the Teatro San Carlo in Naples (1817)—may be still valid today: "L'indole della propagazione del suono è tuttora nel nostro teatro reputata da molti come un mistero ignoto, e da molti altri erroneamente definita" (Until the present day, the nature of sound propagation is considered by many as an unknown mystery, and it is erroneously defined by many others).

Author Contributions: Conceptualization and methodology, D.D.; Investigation, D.D. and S.N.; Writing-Original Draft, D.D. and S.N.

Funding: This research received no external funding.

Acknowledgments: The authors acknowledge Elena Bo for her contribution about ancient theatre and the work of Vitruvius, Lorenzo Fecchio for his suggestions on the works by Sebastiano Serlio and Andrea Palladio, and Valentina Sartini for bibliographic research and for the use of Figures 20 and 21.

Conflicts of Interest: The authors declare no conflict of interest.

\section{References and Notes}

1. Sabine, W. Collected Papers on Acoustics; Harvard University Press: Cambridge, MA, USA, 1922.

2. Kwon, Y.; Siebein, G.W. Chronological analysis of architectural and acoustical indices in music performance halls. J. Acoust. Soc. Am. 2006, 128, 654-663.

3. Barbieri, P. The acoustics of Italian opera houses and auditoriums. Recercare 1998, X, 263-328.

4. Barbieri, P. The state of architectural acoustics in the late renaissance. In Architettura e Musica Nella Venezia del Rinascimento; Howard, D., Moretti, L., Eds.; B. Mondadori: Milan, Italy, 2006. 
5. Postma, B.N.J.; Jouan, S.; Katz, B.F.G. Pre-Sabine room acoustic design guidelines based on human voice directivity. J. Acoust. Soc. Am. 2018, 143, 2428. [CrossRef] [PubMed]

6. Vitruvius. I dieci libri dell'architettura [...] tradotti e commentati da Mons. Daniel Barbaro; Ten Books of Architecture); de' Franceschi: Venezia, Italy, 1567. (In Italian)

7. Biancani, G. Sphaera Mundi seu Cosmographia, ac Facili Methodo Tradita; Sebastiano Bonomi for Geronimo Tamburini: Bologna, Italy, 1620. (In Latin)

8. Postma, B. A history of the use of time intervals after the direct sound in concert hall design before the reverberation formula of Sabine became generally accepted. Build. Acoust. 2013, 20, 157-176. [CrossRef]

9. Fabbri, P.; Farina, A.; Fausti, P.; Pompoli, R. The second life of the Teatro degli Intrepidi by Giovan Battista Aleotti through the new techniques of virtual acoustics. In Proceedings of the 2nd International Conference on Acoustic and Musical Research, Ferrara, Italy, 19-21 May 1995. (In Italian)

10. Cammarata, G.; Fichera, A.; Pagano, A.; Rizzo, G. Acoustical prediction in some Italian theatres. Acoust. Res. Lett. Online 2001, 2, 61. [CrossRef]

11. Prodi, N.; Pompoli, R. The acoustics of three Italian historical theatres: The Early days of modern performance spaces. In Proceedings of the Tecniacustica 2000, Madrid, Spain, 16-20 October 2000.

12. Tronchin, L. Francesco Milizia (1725-1798) and the Acoustics of his Teatro Ideale (1773). Acta Acust. United Acust. 2013, 99, 91-97. [CrossRef]

13. Weinzierl, S.; Sanvito, P.; Schultz, F.; Büttner, C. The acoustics of renaissance theatres in Italy. Acta Acust. 2015, 101, 632-641. [CrossRef]

14. Iannace, G.; Ianniello, C.; Maffei, L.; Romano, R. Objective measurement of the listening condition in the old Italian opera house "Teatro di San Carlo". J. Sound Vib. 2000, 232, 239-249. [CrossRef]

15. Farina, A. Acoustic quality of theatres: Correlations between experimental measures and subjective evaluations. Appl. Acoust. 2001, 62, 899-916. [CrossRef]

16. Pompoli, R. (Ed.) Proc. of Teatri d'opera dell'Unità d'Italia (Proc. of Opera houses of the Italian Unification); Associazione Italiana di Acustica: Venezia, Italy, 2011.

17. Cirillo, E.; d'Alba, M.; Martellotta, F. Acoustic characterisation of Apulian historical theatres. In Proceedings of the 38 Congress of Italian Acoustic Association, Rimini, Italy, 8-10 June 2011. (In Italian)

18. Ceniccola, G. Architetture in scena. Teatri storici in Campania tra XVIII e XX secolo: Conoscenza e nodi critici nel progetto di conservazione (Performance Architecture. Historical Theatres in Campania between 18th and 20th Century: Knowledge and Criticalities in the Conservation Project). Ph.D. Thesis, University of Naples "Federico II", Naples, Italy, 2011.

19. Garai, M.; Morandi, F.; D'Orazio, D.; De Cesaris, S.; Loreti, L. Acoustic measurements in eleven Italian opera houses: Correlations between room criteria and considerations on the local evolution of a typology. Build. Environ. 2015, 94, 900-912. [CrossRef]

20. Prodi, L.; Pompoli, R.; Martellotta, F.; Sato, S. Acoustics of Italian Historical Opera Houses. J. Acoust. Soc. Am. 2015, 138, 769-781. [CrossRef] [PubMed]

21. De Cesaris, S.; Morandi, F.; Loreti, L.; D'Orazio, D.; Garai, M. Notes about the early to late transition in Italian theatres. In Proceedings of the 22nd International Congress on Sound and Vibration (ICSV22), Florence, Italy, 12-16 July 2015.

22. Morandi, F.; De Cesaris, S.; D’Orazio, D.; Garai, M. Energy criteria in Italian historical opera houses: A survey over 11 theatres. In Proceedings of the 9th International Conference on Auditorium Acoustics, Paris, France, 29-31 October 2015; Volume 37.

23. Garai, M.; De Cesaris, S.; Morandi, F.; D'Orazio, D. Sound energy distribution in Italian opera houses. Proc. Mtgs. Acoust. 2016, 28, 015019.

24. Serlio, S. Sette libri dell'architettura di Sebastiano Serlio Bolognese (Seven Books of Architecture); Francesco de'Franceschi senese: Paris, France, 1545. (In Italian)

25. Mazzucato, T. Idea del espacio escénico y lugares para la representación teatral entre los siglos XV y XVI. Modelos de teatro a la manera de Italia (Idea of the Scenic Space and Places for Theatre Performance between the 15th and the 16th Century. Models for the Italian Theatre). Studia Aurea 2009, 3, 139-172. (In Spanish)

26. Canac, F. L'acoustique des Theatres Antiques: Ses Insegnements (The Acoustics of Ancient Theatres: Its Lessons); Edition du Centre National de la Recherche Scientifique: Paris, France, 1967. (In French)

27. Maconie, R. Musical Acoustics in the Age of Vitruvius. Music. Times 2005, 146, 75-82. [CrossRef] 
28. Farnetani, A.; Prodi, N.; Pompoli, R. On the acoustic of ancient Greek and Roman Theatres. J. Acoust. Soc. Am. 2008, 124, 157-167. [CrossRef] [PubMed]

29. Chourmouziadou, K.; Kang, J. Acoustic evolution of ancient Greek and Roman theatres. Appl. Acoust. 2008, 69, 514-529. [CrossRef]

30. Mo, F.; Wang, J. The Conventional RT is Not Applicable for Testing the Acoustical Quality of Unroofed Theatres. Build. Acoust. 2013, 20, 81-86. [CrossRef]

31. Amadei, D. L'ordine e la geometria nel teatro antico. Diffusione e fortuna del De Architectura di Vitruvio. Caso studio: Il teatro romano di Fanum Fortunae (Order and Geometry in the Ancient Theatre. Diffusion and Fame of Vitruvius's De Architectura. ase Study: The Roman Theatre of Fanum Fortunae). Ph.D. Thesis, Polytechnic University of Marche, Ancona, Italy, 2015. (In Italian)

32. Mullin, D.C. The Influence of Vitruvius on Theatre Architecture. Educ. Theatre J. 1966, 18, 27-33. [CrossRef]

33. Torello-Hill, G. The exegesis of Vitruvius and the creation of theatrical spaces in Renaissance Ferrara. Renaiss. Stud. 2014, 29. [CrossRef]

34. Sanvito, P.; Weinzierl, S. L'acustica del Teatro Olimpico di Vicenza (The Acoustics of the Teatro Olimpico in VIcenza). Odeo Olimpico 2013, 23, 463-492. (In Italian)

35. Pigafetta, F. Due Lettere descrittive l'una dell'ingresso a Vicenza della Imperatrice Maria d'Austria dell'anno MDLXXXI l'altra della Recita nel Teatro Olimpico dell'Edippo di Sofocle nel MDLXXXV (Two Letters on the Arrival of Maria of Austria in 1581 and on the Performance at the Teatro Olimpico of Sofocles's Oedipus in 1585); Crescini, V., Ed.; Raccolta di Lettere Sulla Pittura, Scultura ed Architettura: Padova, Italy, 1830; pp. $25-31$. (In Italian)

36. Farneti, F.; Van Riel, S. L'architettura teatrale in Romagna 1757-1857 (Theatrical Architecture in Romagna); Uniedit: Firenze, Italy, 1975. (In Italian)

37. Scamozzi, O.B. Le fabbriche e i disegni di Andrea Palladio (Andrea Palladio's Works); Giovanni Rossi: Vicenza, Italy, 1796. (In Italian)

38. Scamozzi, V. L'idea della architettura universale (About of Universal Architecture); Expensis Auctoris: Venezia, Italy, 1615. (In Italian)

39. Stone Peters, J. Theatre of the Book 1480-1880. Print, Text, and Performance in Europe; Oxford University Press: Oxford, UK, 2000.

40. Crabtree, S.; Beudert, P. Scenic Art for the Theatre; Focal Press: London, UK, 1998.

41. Peacock, J. The Stage Designs of Inigo Jones: The European Context; Cambridge University Press: Cambridge, UK, 1995.

42. Bjurstrom, P. Giacomo Torelli and Baroque Stage Design; Almqvist \& Wiksell: Stockholm, Sweden, 1961.

43. Sabbatini, M. Pratica di Fabricar Scene e Machine Ne' teatri (On Making Scenes and Machines for Theatres); CNR IRCrES: Ravenna, Italy, 1638. (In Italian)

44. Lazardzig, J.; Rössler, H. (Eds.) Technologies of Theatre: Joseph Furttenbach and the Transfer of Mechanical Knowledge in Early Moderne Theatre Cultures; Verlag Vittorio Klostermann: Frankfurt, Germany, 2016.

45. Donati, P. Descrizione del Gran Teatro Farnesiano di Parma e notizie storiche sul medesimo di Paolo Donati parmigiano architetto teatrale e accademico di Bologna e professore della Reale Accademia di Firenze (Description of the Farnese Theatre in Parma and Historical Information ... ); Blanchon: Parma, Italy, 1817.

46. Mariano, F. Il Teatro Nelle Marche: Architettura, Scenografia e Spettacolo (The Theatre in the Marche: Architecture, Scenography and Show); Banca delle Marche: Ancona, Italy, 1997. (In Italian)

47. Quagliarini, E. Costruzioni in Legno nei Teatri All'Italiana del '700 e '800: Il Patrimonio Nascosto Dell'architettura Teatrale Marchigiana (Wooden buildings in Italian Historical Opera Houses: The Hidden Heritage of Theatrical Architecture); Allinea: Firenze, Italy, 2008. (In Italian)

48. Carini Motta, F. Treaty about the Structure of the Theatres and of the Scenes; Guastalla, 1676; Republished; Il Polifilo: Milano, Italy, 1972. (In Italian)

49. Donnelly, M.C. Theaters in the Courts of Denmark and Sweden from Frederik II to Gustav III. J. Soc. Arch. Hist. 1984, 43, 328-340. [CrossRef]

50. Sartini, V. Comparative Analysis of Five Small Sized Italian Theatres of the 19th Century. Master's Thesis, University of Bologna, Bologna, Italy, 2012.

51. Galli Bibiena, F. L'architettura Civile Preparata su la Geometria e Ridotta Alle Prospettive (Civil Architecture: Geometry and Perspective); Paolo Monti: Parma, Italy, 1711. (In Italian) 
52. Algarotti, F. Saggio Sopra L'opera in Musica (Essay on Opera), 2nd ed.; Library of Congress: Washington, DC, USA, 1764. (In Italian)

53. Giordano, L. Il Teatro dei Quattro Cavalieri e la presenza di Antonio Galli Bibiena a Pavia (The "Teatro dei Quattro Cavalieri" and the work of A. Galli Bibiena in Pavia). Bollettino D'arte 1975, 60, 88-102. (In Italian)

54. Planelli, A. Dell'opera in Musica. Trattato del Cavaliere Antonio Planelli Dell'ordine Gerosolimitano (About the Opera); D. Campo: Napoli, Italy, 1772. (In Italian); re-published and edited by F. Degrada; Discanto edizioni: Fiesole, Italy, 1981. (In Italian)

55. Riccati, G. Della Costruzione De' Teatri Secondo il Costume d'Italia: Vale a Dire Divisi in Piccole Logge (About the Construction of Theatres According to the Italian Style, I.e., With Small Boxes); Remondini from Venice: Bassano, Italy, 1790. (In Italian)

56. Barbieri, P. Giordano Riccati Fisico Acustico e Teorico Musicale (Giordano Riccati Acoustician and Musical Theorist); Leo S. Olschki: Florence, Italy, 1990; pp. 279-304. (In Italian)

57. Bagni, G.T. Vincenzo, Giordano, Francesco Riccati e la matematica del settecento (V., G.; F. Riccati and Mathematics in the 18th Century); Teorema: Treviso, Italy, 1993. (In Italian)

58. Bortolozzo, R. L'universo ben Temperato Dei Riccati: Cosmologia e Musica in Una Famiglia di Illuministi Trevigiani (The Well Tempered Universe of the Riccati Family ... ); Il Cardo: Venezia, Italy, 1995. (In Italian)

59. Rizzetti, F. Memoria intorno alla più perfetta costruzione di un Teatro. as quoted in Riccati, 1790.

60. Rizzetti, L. Risposta del sig. Conte Luigi Rizzetti alle accuse date al Teatro da lui proposto (Response [...] to the allegations made to the theatre he proposed). In Collection of Scientific and Literary Brochures; Stamperia Coleti: Ferrara, Italy, 1792. (In Italian)

61. Morelli, C. Pianta e Spaccato Del Nuovo Teatro d'Imola (Plan and Section of the New Theatre of Imola); Casaletti: Roma, Italy, 1780. (In Italian)

62. Matteucci, A.M.; Lenzi, D. Cosimo Morelli e L'architettura Delle Legazioni Pontificie (Cosimo Morelli and the Architecture of the Papal States); University Press Bologna: Imola, Italy, 1977. (In Italian)

63. Memmo, A. Semplici lumi tendenti a render cauti $i$ soli interessati nel teatro da erigersi nella parocchia di $S$ Fantino in Venezia [...] (Simple Hints for Those Who Are Interested in the Theatre to Build in the Parish of S. Fantino in Venice). 1790. (In Italian)

64. Lamberti, V. La regolata costruzion de' teatri secondo il costume d'Italia, vale a dire divisi in picciole logge ... (Italian Construction of Theatres, i.e., Divided in Boxes ... ); V. Orsini: Napoli, Italy, 1782. (In Italian)

65. Saunders, G. Treatise on Theaters; I. and J. Taylor: London, UK, 1790.

66. Available online: https:/ / www.theatre-architecture.eu (accessed on 8 February 2019).

67. D'Alembert, J.; Diderot, D. "Theatre” in Encyclopédye ou Dictionaire raisonnè des Sciences, des Arts et del Métiers; Briasson: Paris, France, 1751-1772. (In French)

68. Bondin, N. Teatro Antico. Ragionamento Sopra la Forma e la Struttura (Ancient Theatre. Reasoning on Form and Structure); s.e.: Venezia, Italy, 1746. (In Italian)

69. Cochin, C.-N. Lettre sur les salles de spectacle, Mercure de France (Letter on Musical Halls). 1760. (In French)

70. Dumont, G.M. Suite de projects détaillés de salles de spectacle, avec del principes de construction, tant pour la mécanique del theatres que pour das décoration... (Set of Detailed Projects of Performance Halls, with Construction Principles, both for Theatre Mechanics and Decoration). Paris, France, 1773. (In French)

71. De La Dixmerie, N.B. Lettres sur l'etat present de nos spectacles, avec del vues nouvelles sur chacun d'eux, particulierement sur la Comedie Francaise et l'Opera (Letters on the Present Situation of Our Performances, with New Opinions, Especially on the Comedie Française and l'Opéra); Duchesne: Amsterdam, The Netherlands; Paris, France, 1765. (In French)

72. Chaumont, D.J. (Veritable construction exterieure d'un theatre d'Opera, a l'usage de France, relative a celle donnee l'annee dernere, pour la Construction interieure (Exterior Construction of a French Style Opera House, Related to the One Published Last Year, Related to the Interior); De Lormel: Paris, France, 1766. (In French)

73. Monginot, G.M. Exposition des principes qu'on doit suivre dans l'ordonnance des theatre modernes; C.A. Jombert: Paris, France, 1769. (In French)

74. Damun, J. Prospectus du noveau theatre tracé sur les principes des Grecs et des Romains (Project of a New Theatre Based on Greek and Roman Principles). Paris, France, 1772. (In French)

75. Roubo le Fils, A.J. Traité de la construction des theatres et des machines theatrales (Treatise on the Construction of Theatres and Theatre Machines); Cellot et Jombert: Paris, France, 1777. (In French) 
76. Patte, P. Description du theatre de la ville de Vicence en Italie, chef-d'oeuvre d'Andrea Palladio (Description of the Theatre of Vicenza, in Italy, Work by Andrea Palladio). Paris, France, 1780. (In French)

77. Noverre, J.G. Observations sur la construction d'une salle d'Opera (Observation on the Construction of an Opera House); Cellot: Paris, France, 1781. (In French)

78. Patte, P. Essai sur l'architecture théatrale, ou, De l'ordonnance la plus avantageuse à une salle de spectacles, relativement aux principes de l'optique et de l'acoustique: Avec un examen des principaux téatres de l'Europe, et une analyse des écrits les plus importans sur cette matiere (Essay on Theatre Architecture, or on the Most Advantageous Design of a Performance Hall, and an Analysis of the Most Important Writings on This Topic); Moutard: Paris, France, 1782. (In French)

79. Bouellet. Essai sur l'art de construire les theatres, leurs machines et leur mouvements (Essay on the Art of Building Theatres, their Machines and their Movements); Ballard: Paris, France, 1801. (In French)

80. Grobert, J.-F.-L. Exécution dramatique en rapport avec le materiel de la Salle et de la Scene (Dramatic Execution rEgarding the Materials of the Hall and the Scene); Schoell: Paris, France, 1809. (In French)

81. Ledoux, C.N. L'architecture considerée sour le rapport de l'Art, des Moeurs et de la Legislation ... (The Architecture Considered through the Connections with Art, Traditions and Law). Paris, France, 1804. (In French)

82. Boullée, E.L. Architecture, Essai sur l'art (Architecture, Essay on Art). London, UK, 1953. (In French)

83. Tamburini, E. Il luogo teatrale nella trattatistica italiana dell'800 (The Theatrical Space in Italian 19th-Century Treatises); Bulzoni Editore: Roma, Italy, 1984. (In Italian)

84. Barbieri, P.; Tronchin, L. L'impostazione acustica dei teatri nei progetti del primo neoclassicismo Italiano (1762-1772), (The Acoustical Structure of Theatres in the First Italian Neoclassical Projects). In Francesco Milizia e il teatro del suo tempo Architettura, Musica, Scena, Acustica; Russo, M., Ed.; Collana Studi e Ricerche n. 2: Trento, Italy, 2011; pp. 137-161, ISBN 978-88-8443-396-1. (In Italian)

85. Arnaldi, E. Idea di un teatro nelle principali sue parti simile a' teatri antichi all' uso moderno accomodato; Veronese: Vicenza, Italy, 1762. (In Italian)

86. Milizia, F. Trattato completo, formale e materiale del teatro (About the Theatre); Pasquali: Venezia, Italy, 1773-1794. (In Italian)

87. D'Orazio, D.; De Cesaris, S.; Morandi, F.; Garai, M. The aesthetics of the Bayreuth Festspielhaus explained by means of acoustic measurements and simulations. J. Cult. Herit. 2018, 34, 151-158. [CrossRef]

88. Westfall, C.W. Antolini's Foro Bonaparte in Milan. J. Warbg. Courtauld Inst. 1969, 32, 366-385. [CrossRef]

89. Beccega, T. Sull'architettura greco-romana applicata alla costruzione del teatro moderno italiano e sulle macchine teatrali (On the Application of the Graeco-Roman Architecture to the Construction of the Modern Italian Theatre and to the Theatrical Machines). Alvisopoli, Italy, 1817. (In Italian)

90. Niccolini, A. Alcune idee sulla risonanza del teatro (Some Ideas on the Resonance of the Theatre); Masi: Napoli, Italy, 1816. (In Italian)

91. Landriani, P. Osservazioni sui difetti prodotti nei teatri dalla cattiva costruzione del palco scenico e su alcune inavvertenze nel dipingere le decorazioni (Observations on the Flaws Deriving by the Poor Construction of the Stage and on Some Oversights in Decoration Paintings); Regia tipografia di Milano: Milan, Italy, 1828. (In Italian)

92. Meduna, T.; Meduna, G. Il Teatro La Fenice in Venezia ... (On the La Fenice Theatre ... ); Antonelli: Venezia, Italy, 1849 . (In Italian)

93. Cocchi, A.; Garai, M.; Tronchin, L. Influenza di cavità risonanti poste sotto la fossa orchestrale: Il caso del teatro Alighieri di Ravenna (The Influence of Resonating Cavities under the Orchestra Pit: The Case of the Alighieri Theatre in Ravenna). In Teatri storici. Dal restauro allo spettacolo; Nardini Editore: Firenze, Italy, 1997; pp. 135-153.

94. D’Apuzzo, N. Cenno intorno ai teatri moderni e sopra gli archi di trionfo degli antichi (Notes on Modern Theatres and Ancient Triumphal Arches). 1817. (In Italian)

95. De Grazia, V. Discorso sull'architettura del teatro moderno (On the Architecture of the Modern Theatre). 1825. (In Italian)

96. Ferrario, G. Storia e descrizione de' principali teatri antichi e moderni (History and Description of the Main Ancient and Modern Theatres). Forni, Italy, 1830. (In Italian)

97. de Cesare, F. La scienza dell'architettura applicata alla costruzione, alla distribuzione, alla decorazione degli edifici civili (The Science of Architecture on the Construction, Distribution and Decoration of Civil Buildings). 1885. (In Italian) 
98. D'Orazio, D.; De Cesaris, S.; Garai, M. Recordings of Italian opera orchestra and soloists in a silent room. Proc. Meet. Acoust. 2016, 28, 015014. [CrossRef]

99. Barbera, P. Giuseppe Damiani Almeyda artista architetto ingegnere (Giuseppe Damiani Almeyda Artist, Architect, Engineer); Pielle Edizioni: Palermo, Italy, 2008.

100. Boniotto, E.; Bovo, M.E.; Di Bella, A.; Frinzi, G.; Granzotto, N.; Rinaldi, C.; Zecchin, R. L'acustica nel restauro dei teatri storici: Il caso del Teatro Civico Di Schio (The Acoustics in the Restoration of Historical Theatres. The Case of the City Theatre in Schio). In Proceedings of the Congress of Italian Association of Acoustics, Ischia, Italy, 10-12 May 2006.

101. Silingardi, V.; Rinaldi, C.; Granzotto, N.; Barbaresi, L.; di Bella, A. A restoration based on the result of a public debate: The case of Civic Theatre of Schio. Rivista Italiana di Acustica 2017, 41, 1-14.

102. Basile, G.B.F. Sulla costruzione del Teatro Massimo Vittorio Emanuele (On the Construction of Teatro Massimo Vittorio Emanuele); Tip. Dello Statuto: Palermo, Italy, 1883. (In Italian)

103. Fundaró, A.M. Il Concorso per il Teatro Massimo di Palermo—Storia e progettazione (Competition for the Teatro Massimo in Palermo: History and Design); STASS: Palermo, Italy, 1974

104. Canoppi, A. Opinion ... sul l'architecture en général et en spécialité sul la construction des Théatres modernes (On Modern Theatres and Ancient Triumphal Arches). 1830. (In French)

105. Bortolotti, L.; Masetti, L. Teatri storici. Dal restauro allo spettacolo (Historical Theatres. From Renovation to Performance); Nardini: Fiesole, Italy, 1977. (In Italian)

106. Savini, F. Cenni storici e vicende del Teatro Comunale di Cesenatico (Historical Information on the City Theatre of Cesenatic). Cesenatico, Italy, 1979.

107. Fabbri, P. Teatri di Russi, dal vecchio al nuovo Comunale (The City Theatre in Russi, from the Old to the New); Longo Editore: Ravenna, Italy, 1979.

108. Van Riel, S. (Ed.) Il Teatro di Meldola: Storia e Restauro (The Theatre in Meldola: History and Renovation); Alinea: Firenze, Italy, 1982.

109. Castagnoli, S. Il teatro "E. Petrella" di Longiano dalla fabbrica al restauro (The Theatre Petrella in Longiano, from Design to Renovation). In Studi Romagnoli; XXXVI; La Fotocromo Emiliana: Bologna, Italy, 1985. (In Italian)

110. Bortolotti, L. (a cura di), Le stagioni del teatro. Le sedi storiche dello spettacolo in Emilia Romagna; Grafis Industrie Grafiche: Bologna, Italy, 1995.

111. Ceredi, C.; Piraccini, O. (Eds.) Teatro Comunale di Cesenatico (City Theatre in Cesenatico). Comune di Cesenatico, Italy, 2004.

112. Vasumi Roveri, E. I teatri di Romagna. Un sistema complesso (The Theatres of Romagna: A Complex System); Compositori Editore: Bologna, Italy, 2005. (In Italian)

113. D'Orazio, D.; De Cesaris, S.; Guidorzi, P.; Barbaresi, L.; Garai, M.; Magalotti, R. Room acoustic measurements using a high SPL. In Proceedings of the 140th AES Convention, Paris, France, 4-7 June 2016.

114. ISO 3382-1. Acoustics-Measurement of Room Acoustic Parameters. Part 1: Performance Spaces; ISO: Geneva, Switzerland, 2009.

115. Guidorzi, P.; Barbaresi, L.; D’Orazio, D.; Garai, M. Impulse responses measured with MLS or Swept-Sine signals applied to architectural acoustics: An in-depth analysis of the two methods and some case studies of measurements inside theaters. Energy Procedia 2015, 78, 1611-1616. [CrossRef]

(C) 2019 by the authors. Licensee MDPI, Basel, Switzerland. This article is an open access article distributed under the terms and conditions of the Creative Commons Attribution (CC BY) license (http://creativecommons.org/licenses/by/4.0/). 